\title{
Review \\ DNA Methylation Malleability and Dysregulation in Cancer Progression: Understanding the Role of PARP1
}

\author{
Rakesh Srivastava ${ }^{1}$ (D) and Niraj Lodhi ${ }^{2, *}$ (D) \\ 1 Molecular Biology and Biotechnology Division, CSIR-National Botanical Research Institute, \\ Lucknow 226001, India; raakeshshrivastav@yahoo.com \\ 2 Clinical Research (Research and Development Division) Mirna Analytics LLC, Harlem Bio-Space, \\ New York, NY 10027, USA \\ * Correspondence: lodhinirajp@gmail.com
}

Citation: Srivastava, R.; Lodhi, N. DNA Methylation Malleability and Dysregulation in Cancer Progression: Understanding the Role of PARP1. Biomolecules 2022, 12, 417. https:// doi.org/10.3390/biom12030417

Academic Editor: Mark S. Johnson

Received: 31 December 2021

Accepted: 4 March 2022

Published: 8 March 2022

Publisher's Note: MDPI stays neutral with regard to jurisdictional claims in published maps and institutional affiliations.

Copyright: (C) 2022 by the authors. Licensee MDPI, Basel, Switzerland. This article is an open access article distributed under the terms and conditions of the Creative Commons Attribution (CC BY) license (https:// creativecommons.org/licenses/by/ $4.0 /)$.

\begin{abstract}
Mammalian genomic DNA methylation represents a key epigenetic modification and its dynamic regulation that fine-tunes the gene expression of multiple pathways during development. It maintains the gene expression of one generation of cells; particularly, the mitotic inheritance of geneexpression patterns makes it the key governing mechanism of epigenetic change to the next generation of cells. Convincing evidence from recent discoveries suggests that the dynamic regulation of DNA methylation is accomplished by the enzymatic action of TET dioxygenase, which oxidizes the methyl group of cytosine and activates transcription. As a result of aberrant DNA modifications, genes are improperly activated or inhibited in the inappropriate cellular context, contributing to a plethora of inheritable diseases, including cancer. We outline recent advancements in understanding how DNA modifications contribute to tumor suppressor gene silencing or oncogenic-gene stimulation, as well as dysregulation of DNA methylation in cancer progression. In addition, we emphasize the function of PARP1 enzymatic activity or inhibition in the maintenance of DNA methylation dysregulation. In the context of cancer remediation, the impact of DNA methylation and PARP1 pharmacological inhibitors, and their relevance as a combination therapy are highlighted.
\end{abstract}

Keywords: DNA demethylases; DNA demethylases inhibitors; PARP1; poly(ADP-ribose); DNA methylation; tumor suppressor gene; oncogene; tumor progression; cancer cells

\section{Introduction}

Epigenetic processes are functional chromatin alterations that occur as a result of heritable changes in the genes or genome that are not caused by changes in the nucleotide sequences. These precise epigenetic markers undergo dynamic alterations during development and cellular differentiation, which eventually aid in the maintenance and generation of diverse types of cells in an organism [1]. Epigenetic processes play a part in the various phases of cell differentiation as set out by the precursor or primary cells; cells have a DNA sequence similar to that of primary cells, which also give them long-term cellular memory for cell differentiation. Epigenetic modifications are likely to have a substantial influence on the onset and progression of many diseases. Epigenetics has added unique insights to disease traits that cannot be explained by genetic or environmental causes, enriching human disease knowledge. Epigenetic changes are being utilized to understand several basic features of complex diseases, such as late-onset of and variations in disease symptoms [2,3].

The dynamics of DNA methylation are an important epigenetic signature that has been widely researched among epigenetic processes. In recent years, DNA methylation and its dynamic control have been extensively integrated into modern epigenetic encoding models. In mammals, epigenetic modifications of DNA predominantly involve the addition of a methyl group of the cytosine base to carbon five before guanine, subsequently generating 5 -methylcytosine $(5 \mathrm{mC})$. In mammals, the majority of DNA methylation materializes in 
the background of the CpG-dinucleotide framework (characterized by cytosine, guanine and the phosphate group between them). CpG islands are high-density CpG-dinucleotide units found in interspersed areas, primarily in the promoter and regulatory regions [4-8]. The human genome has about 29 million CpG sites, with nearly 60-80\% of them being methylated in normal somatic cells [9]. Surprisingly, CpG sites are not uniformly distributed throughout the genome; in contrast, the majority of the genome is devoid of CpG sites, with just one-fifth of the predicted ratio of $\mathrm{CpG}$ dinucleotides being present [8]. The majority of CpG islands often span gene promoters and housekeeping genes and are 500-1000-basepair (bp) long [10]. Significantly, DNA methylation occurs in $70 \%$ of all CpG dinucleotides and $40 \%$ of genes with CpG-rich islands in the genome [5,11]. Numerous methyl-binding proteins recognize methylated $\mathrm{CpGs}$ as binding sites that participate in the recruitment of chromatin-remodeling protein or machinery, thereby facilitating gene silencing and inactivation, and chromatin condensation [8,12-14]. Methylation on non-CpG regions has also been described to be affecting DNA-protein interactions, chromatin structure and stability, and gene regulation [15]. Non-CpG methylation $(\mathrm{CpH}$, where $\mathrm{H}=\mathrm{A}, \mathrm{C}$, or $\mathrm{T})$ has also been reported in oocytes, human embryonic stem cells and neurons [16-20].

For dynamic chromatin modification, the connection among gene regulation, histone modification and DNA methylation is highly coordinated and synchronized [21-24]. Poly(ADP-ribosyl)ation is a catalytic activation of PARP1 that occurs when it catalyzes the addition of ADP-ribose (ADPr) to a pre-existing chain of poly(ADPr) of target proteins, including itself via auto-poly(ADP-ribosyl)ation $[25,26]$. The activity of PARP1 is engaged in several biological and cellular functions, including histone or chromatin alterations and consequent gene expression modulation. However, the epigenetic mechanism of PARP1 differs from that of DNA methylation because it also enzymatically opens condensed chromatin in advance of transcriptional activity $[27,28]$. The current review expands on PARP1's potential importance as a new therapeutic target for clinical applications by expanding its numerous roles linked with DNA methylation in normal and cancer cells.

\section{Dynamic Behavior of DNA Methylation and Demethylation}

In mammals, cytosine methylation is mostly limited to the symmetrical CpG framework $[19,29]$. To inactivate transcription, methylation is most commonly found in the $\mathrm{CpG}$ islands of target-gene promoter-exon regions. Particularly, CpG islands are found in the promoters of half of all genes [30]. In contrast to CpG-island promoters and shores, gene bodies tend to have a considerate amount of $5 \mathrm{mC}$, which corresponds to active gene expression [10] (Figure 1). CpG-deficient regulatory areas, such as tissue-specific enhancers, are classified as lowly methylated regions, with average DNA-methylation frequencies varying from 10 to 50\% [31] (Figure 1). At verified promoter-enhancer pairings, DNA methylation levels in the enhancer region have been linked to gene activity, with a low level of $5 \mathrm{mC}$ indicating greater gene expression [10,32]. CpG dinucleotides have a low incidence in the human genome, but they are interspersed with sections with high numbers of these sequences that are linked to gene regulatory regions [33]. Particularly, CpG sites are usually methylated across the genome, although sites within $\mathrm{CpG}$ islands are not methylated unless the corresponding gene is silenced. DNA methylation has been connected to non-reversible events, including imprinting, dosage compensation, or the silencing of developmentally regulated genes with cell differentiation, as well as a potentially damaging transposon and virally inserted sequences $[8,34]$. 


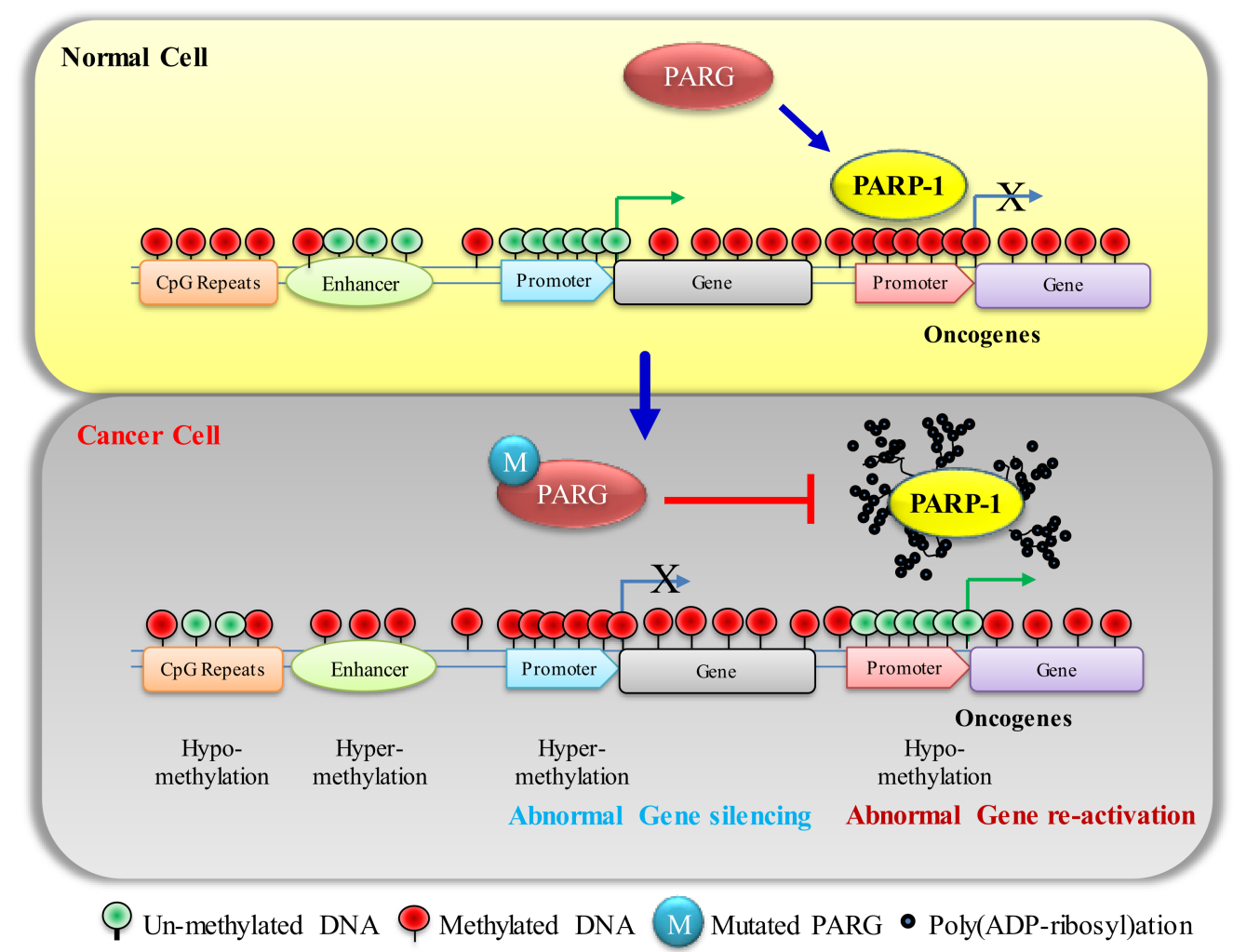

Figure 1. The difference in differential DNA methylation in normal and cancer cells. In PARG or homologous DNA-repair-defective cancer cells the enzymatic activity of PARP1 is increased; therefore, auto-poly(ADP-ribosy)lated PARP1 moves away from the pre-occupied promoter of oncogenes and provides the access to transcription machinery for expression. In downstream, it facilitates DNA hypomethylation at the promoters of oncogenes and make them transcriptional active De novo DNA methyltransferases (DNMTs) promote DNA methylation by catalyzing the transfer of a methyl group from donor S-adenosyl-l-methionine (SAM) to cytosine bases to produce $5 \mathrm{mC}$. The DNMT family consists of five members-DNMT1, DNMT2, DNMT3A, DNMT3B and DNMT3L (Figure 2A) [35,36]. Interestingly, DNMTs' important actions during DNA methylation may be divided into two categories, methylation maintenance and de novo methylation. DNA methylation is predominantly maintained by DNMT1, which facilitates copying DNA methylation patterns during DNA replication in the $S$ phase of mitosis and meiosis [37]. The epigenetic mark can then self-replicate because of DNMT maintenance, which recognizes mono-methylation and methylates the CpG site's complementary strand, leading to a di-methylated tag. Double-stranded methylation, during which the two methyl groups accept a syn conformation in the major groove, can modulate chromatin architecture and regulate gene transcription [38]. DNMT3A and DNMT3B are de novo methyltransferases; they potentially develop a new DNA methylation signature for unmethylated CpGs of DNA and are recognized as de novo DNMT enzymes [39,40]. DNMT3A or DNMT3B catalyzes the methylation of previously unmethylated DNA (de novo methylation) in embryonic stem cells and tumor cells [41]. DNMT3A and DNMT3B can also aid in the maintenance of DNA methylation [42,43]. Accumulating evidence suggests that DNMT3L (DNMT3-like) has no catalytic activity because some crucial motifs have been lost or altered [44]. However, DNMT3L contributes as an essential cofactor for de novo methyltransferase by expediting the interaction among DNMT3A, DNMT3B and DNA, and stimulating their activity $[39,40,45,46]$. 
A
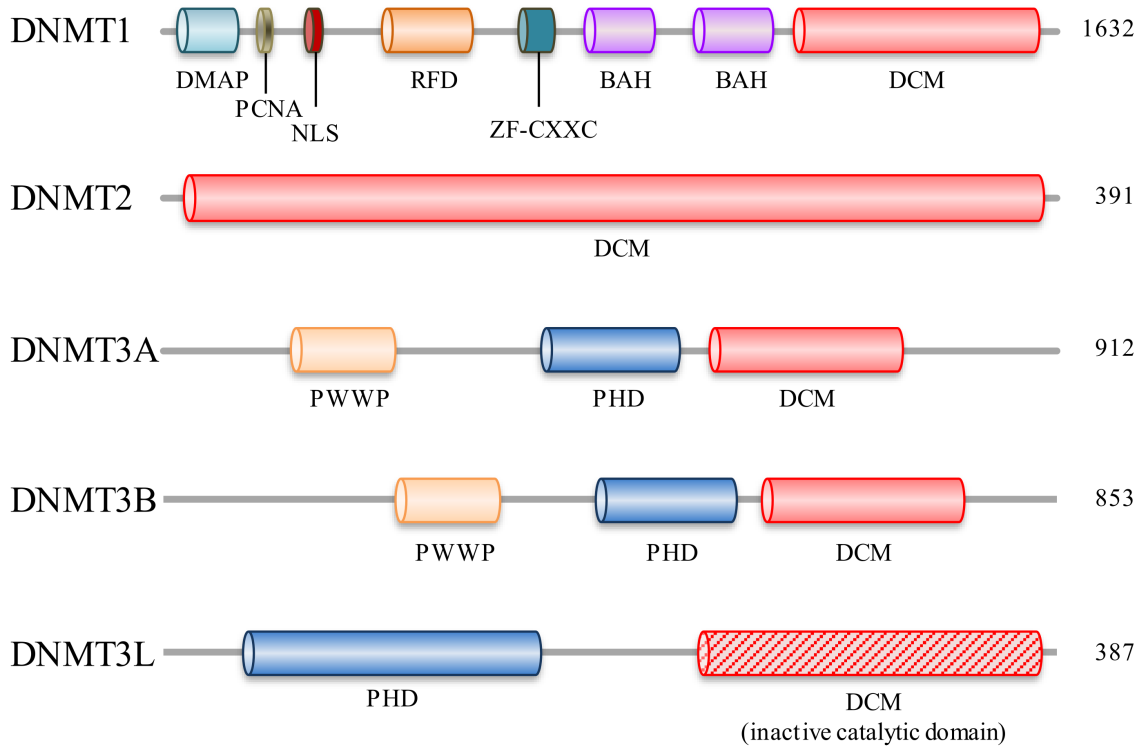

B

TET1

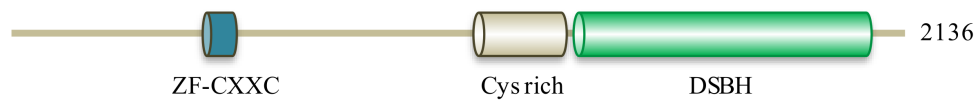

TET2

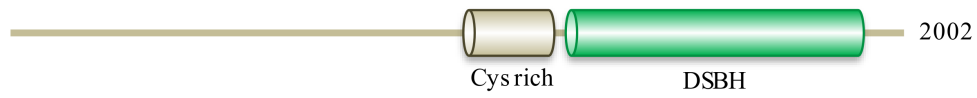

TET3

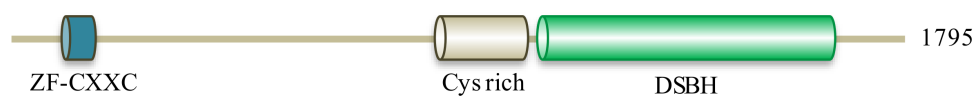

C

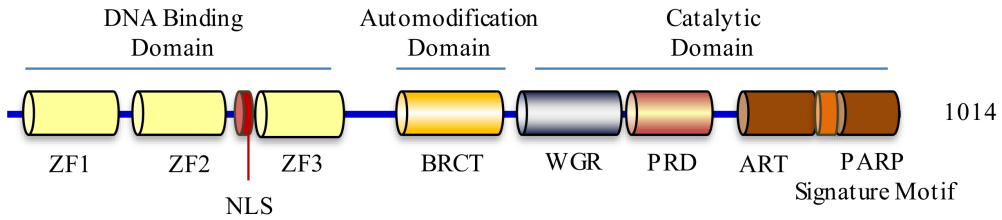

Figure 2. Schematic structure of human DNMT, DNMT3-like, TET family and PARP1 proteins. (A) DMAP, DMAP1-binding domain; PCNA, Proliferating Cell Nuclear Antigen domain; NLS, Nuclear Localization Signal domain; DNMT1-RFD, Cytosine-specific DNA methyltransferase replication foci domain; Zf-CXXC, CXXC zinc finger domain; BAH, Bromo adjacent homology domain; DCM, DNA-cytosine methylase; Cyt_C5_DNA_methylase, Cytosine-C5 specific DNA methylases; PWWP, domain comprising a conserved proline-tryptophan-tryptophan-proline motif; PHD, plant homeodomain; The sequences are derived from data reported under accession numbers NP_001124295 for DNMT1, NP_004403 for DNMT2, NP_783328 for DNMT3A, NP_008823 for DNMT3B and NP_037501 for DNMT3L. (B) Domain structures of ten-eleven translocation methylcytosine dioxygenases (TETs). Schematic representation of conserved domains of human TET proteins is shown, including a doublestranded-helix (DSBH) fold (all TETs), cysteine-rich (Cys-rich) domain (all TETs) and CXXC zinc fingers (Zf-CXXC; in TET1 and TET3). The sequences are derived from data reported under accession numbers NP_085128 for TET1, NP_001120680 for TET2 and NP_001274420 for TET3. (C) Domain structure of PARP1. PARP1 has four main domains, an amino (N)-terminal DNA-binding domain, an auto-modification domain, a water-binding domain and a carboxy (C)-terminal catalytic domain. ZFI, zinc finger I; ZF2, zinc finger II; ZF3, zinc finger III; NLS, nuclear localization signal; BRCT, BRCA1 C-terminal domain; PRD, PARP regulatory domain; ART, ADP-ribosyl transferase subdomain. 
During gametogenesis and shortly after fertilization, DNMT3L works as an accessory protein for DNMT3A- and DNMT3B-mediated de novo DNA methylation [47]. Interestingly, only germ cells and embryonic stem cells express DNMT3L; however, no such functions have been reported in somatic cells [48]. DNMT3L, together with DNMT3A and DNMT3b, is primarily expressed in the postnatal female germline for the development of DNA-methylation patterns [49]. DNMT3L is implicated in the regulation of repetitive elements, as well as germ-cell imprinting [47,50]. According to the study, DNMT3L has two roles in the differentiation of embryonic stem (ES) cells; firstly, it works as a positive controller of DNA methylation in the housekeeping-gene part and, secondly, it functions as a negative controller of DNA methylation at bivalent gene promoters [51]. Notably, DNMT2 (also called tRNA aspartic acid methyltransferase 1 (TRDMT1)) exhibits weak activity of methyltransferase in vitro and its removal has an insignificant influence on $\mathrm{CpG}$ methylation levels and no apparent effects on developmental phenotypes [52,53]. On the other hand, the anticodon loop of aspartic-acid transfer RNA is methylated by DNMT2 [54]. Based on genetic factors, DNMT2/TRDMT1-dependent RNA modifications are important in determining the coding signature of sperm small non-coding RNA, which is required for paternal epigenetic memory and in the transmission of paternally acquired metabolic diseases to offspring [44,55].

In comparison to most histone modifications, DNA methylation is rather stable. However, DNA demethylation (the lack of DNA methylation) has been seen in a variety of biological and developmental contexts. Demethylation changes to DNA can occur in two ways, active or passive pathway [56]. In the active DNA demethylation process, the enzymatic removal of or alteration in the methyl group of $5 \mathrm{mC}$ takes place [57]. Passive DNA demethylation, on the other hand, occurs as a result of the loss of maintenance methylation [44]. Passive DNA demethylation happens during multiple cycles of replication due to the absence of efficiently working DNA-methylation maintenance machinery, for instance, DNMT1 suppression or absence of the DNA hypomethylation effect. Passive DNA demethylation can also occur during mammalian development, particularly during pre-implantation development in the maternal genome [44,58,59]. 5mC demethylation to produce 5-hydroxymethylcytosine $(5 \mathrm{hmC})$ commonly primarily involves $5 \mathrm{mC}$ oxidation through ten-eleven translocation (TET) methyl cytosine dioxygenases (Figures 2B and 3). Further, TET enzymes hydroxylate $5 \mathrm{hmC}$ to produce 5 -formylcytosine $(5 \mathrm{fC})$ and 5-carboxylcytosine $(5 \mathrm{caC})$ in a series of steps. Thymine DNA Glycosylase (TDG) recognizes the intermediary bases $5 \mathrm{fC}$ and $5 \mathrm{caC}$ and disrupts the glycosidic bond, leading to an apyrimidinic site. After that, the excision at the base is repaired. In different oxidative deamination mechanisms, 5hmC can be oxidatively deaminated by AID (activation-induced cytidine deaminase)/ APOBEC (apolipoprotein B mRNA editing enzyme catalytic subunit) deaminases to produce 5-hydroxymethyluracil ( $5 \mathrm{hmU}) .5 \mathrm{mC}$ can also be transformed into thymine by activation-induced deaminase (AID) or apolipoprotein B RNA-editing catalytic components $2 \mathrm{~b}$ and $2 \mathrm{a}$ (Apobec2b, 2a). Methyl-CpG Binding Domain 4 (MBD4), Nei Like DNA Glycosylase 1 (NEIL1), TDG and Single-Strand-Selective Monofunctional UracilDNA Glycosylase 1 (SMUG1) can all cleave 5hmU. Base-excision repair (BER) enzymes subsequently repair the apyrimidinic site and T: G mismatches to generate cytosine. The TET family most frequently demethylates DNA by dioxygenases [60]. 


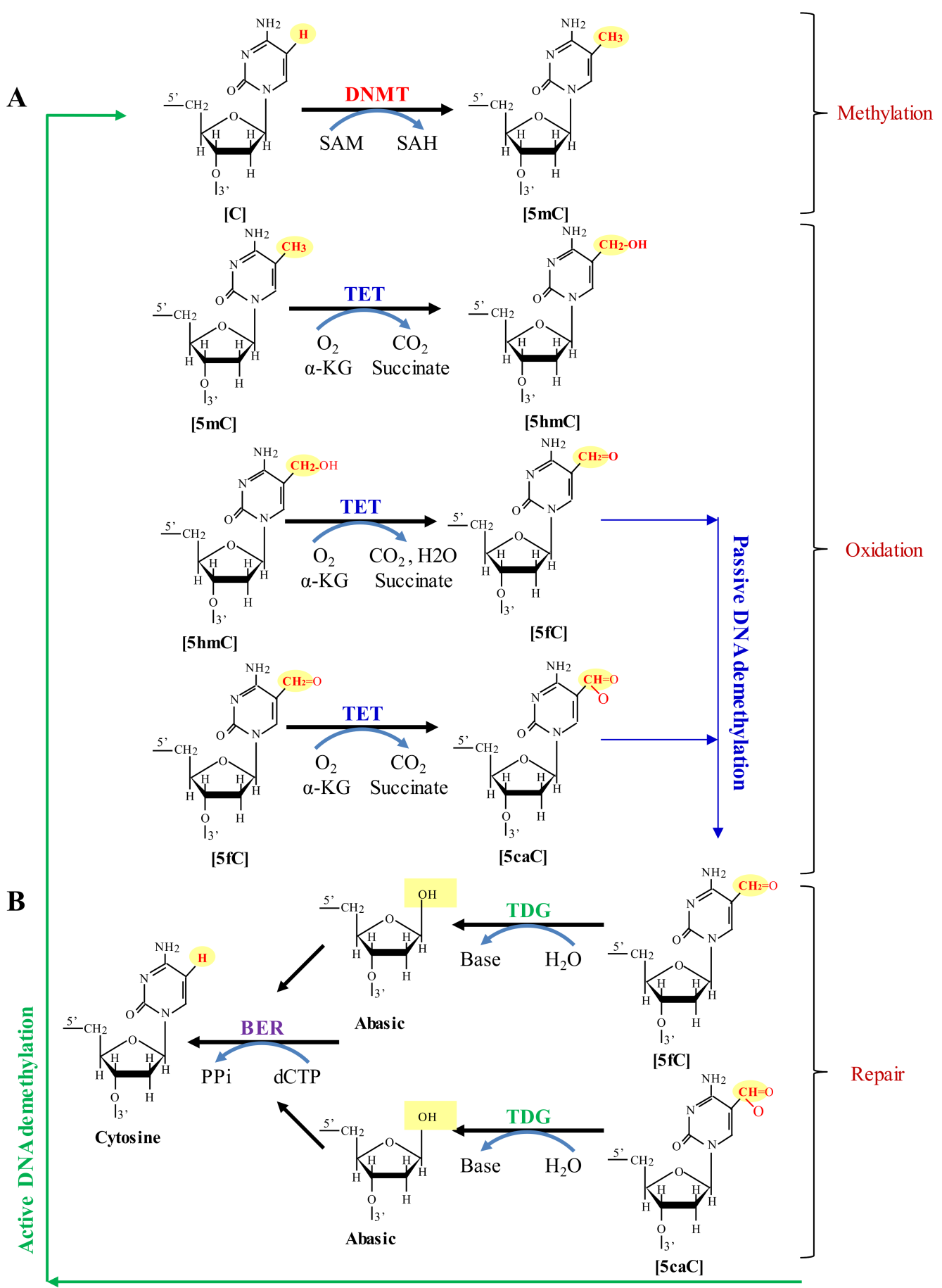

Figure 3. Steps for dynamic modifications of Cytosine and TET-mediated oxidation. (A) The methylation of deoxycytosine $(\mathrm{C})$ residues to 5 -methylcytosine $(5 \mathrm{mC})$ are introduced by DNA methyltransferase (DNMT) enzymes and sequentially oxidized by ten-eleven translocation (TET) enzymes via 5-hydroxymethylcytosine $(5 \mathrm{mC})$, 5-formylcytosine $(5 \mathrm{fC})$ and 5-carboxylcytosine (5caC). SAM, S-adenosylmethionine; SAH, S-adenosylhomocysteine; $\alpha-\mathrm{KG}, \alpha$-ketoglutarate. (B) $5 \mathrm{fC}$ and $5 \mathrm{caC}$ are identified and excised by thymine DNA glycosylase (TDG) to produce an abasic site. The base-excision-repair (BER) pathway implicates excision of the abasic site, replacement of the nucleotide using unmodified deoxycytidine triphosphate (dCTP) by a DNA polymerase (generating pyrophosphate, PPi) and ligation to repair the nick.

Different TET gene isoforms are expressed in various cells and organs. In the TET dioxygenase family, a minimum of two TET1, one TET2 and three TET3 isoforms has been 
reported (Figure 2B) [56,61]. Embryonic stem cells, initial embryo stages and primordial germ cells appear to be the only places where the full-length canonical TET1 isoform is found. The dominant TET1 isoform in most somatic tissues, notably in mice, derives from the activation of an alternative promoter, resulting in a truncated transcript and a smaller protein known as TET1s [62]. TET3 isoforms also include full-length form, TET3FL; a short-form splice form, TET3s; and another variant reported in neurons and oocytes, referred to as TET3O. TET3o is generated by a distinct promoter and contains a unique initial N-terminal exon, which encodes for 11 amino acid residues. There has been no such report yet that TET3o can be found in embryonic stem cells, other cell types, or adult animal tissue. TET1 expression is scarcely detectable in zygotes and oocytes, while TET2 has a low level of expression and the TET3 variation TET3o is almost nonexistent at the two-cell stage. When exceptionally large-scale rapid demethylations occur in neurons, oocytes and zygotes at the one-cell stage, TET3o could be the most common TET enzyme used [56,63-67].

\section{DNA Methylation and Demethylation in Cancer Progression}

Epigenetics is widely documented to play a role in cancer development; a significantly changed epigenome, such as aberrant DNA methylation and histone modification configurations, is now thought to be a typical cancer signature and hallmark. Recent progress has provided the mechanistic insight of DNA methylation-demethylation dynamics, as well as their prospective regulatory roles in cellular differentiation and carcinogenic progression $[10,68,69]$ The phenomena of DNA hypermethylation and tumor-suppressor-gene (TSG) silencing have attracted the most interest in cancer progression. Hypermethylation can, in principle, play a critical role in cancer development and progression. Furthermore, hypomethylation is gradually being recognized as a promising pathway for cancer prometastatic gene activation. The malfunctioning of methylation machinery or of DNMT enzymes has been attributed to the abnormal DNA methylation topography in cancer cells. The finding of $5 \mathrm{hmC}, 5 \mathrm{fC}$ and $5 \mathrm{caC}$, on the other hand, has anticipated that a failure of the demethylation enzymatic system could result in DNA methylation marks asymmetry and reprogramming [70].

Chemical carcinogens or pathological factors can cause genetic mutations that affect DNMT functions or expression levels, resulting in genome-wide methylation profile variations and cancer-stimulating gene-expression alteration, such as reducing TSG expression while boosting genomic instability and oncogene expression $[68,69,71,72]$. Accumulating studies have revealed that gene expression anomalies produced by DNMT activity and function are linked to the incidence and progression of many malignancies (Table S1). Hypermethylation and hypomethylation are thought to be separate mechanisms in cancer that target various programs at different stages of carcinogenesis. Many malignancies exhibit genome-wide hypomethylation and promoter hypermethylation, which are linked to carcinogenesis. Hypomethylation across the genome has been linked to an increase in genomic instability [73,74]. Hypermethylation of $\mathrm{CpG}$ islands in gene promoters, on the other hand, can inhibit TSGs and affect crucial physiological functions, including apoptosis, angiogenesis, cell cycle, cell adhesion and DNA repair [75]. Notably, it has been reported that TET protein expression or function is frequently dysregulated in a variety of malignancies. In vivo, TET deficiency is significantly connected to the start and progression of hematologic malignancies (Table S1). Many forms of malignancies are linked to TET impairments, TET loss-of-function alterations and TET loss of function produced by hypoxia and other regulatory and metabolic disturbances [76].

\section{Poly(ADP-ry)lation of DNMT1 Determines DNA Methylation}

PARP1 is a multifunctional-domain protein (1014 amino acids, $113 \mathrm{kDa})$; its N-terminal domain (1-353 AA) contains three DNA-binding domains (zinc fingers ZF1, ZF2 and ZF3) and a nuclear-localization-sequence domain (NLS) (Figure 2C). ZF1 and ZF2 recognize and bind to damaged DNA sites, while the function of ZF3 is to activate enzymes and NLS leads newly translated PARP1 to the nucleus. The central automodification domain (389- 
643 AA) is an auto-poly(ADP-ribosyl)ation site for PARP1 and functionally very important, composed of BRCT (which mediates protein-protein interactions) and WGR (which interacts with ZF1, ZF3 and catalytic domains) domains. The C-terminal catalytic domain (662-1014 AA) is composed of the NAD acceptor site to perform poly(ADP-ribosyl)ation enzymatic activity [77].

PARP1 was originally known as a DNA-repair enzyme, as until recent years, other functions were not known. Now, we know PARP1 controls the transcription regulation [78], NF- $\mathrm{B}$-dependent immune response [79], ribosome biogenesis, epigenetic inheritance of mechanism of gene expression through mitotic bookmarking [80-82] and differential DNA methylation $[83,84]$. PARP1 is a protein that catalyzes the transfer of ADP-ribose units from $\mathrm{NAD}^{+}$to specific target proteins and controls important physiological processes such as DNA methylation, DNA damage response, chromatin remodeling and gene expression. This process, known as poly(ADP-ribosyl)ation, produces one ADP-ribose and one nicotinamide for every $\mathrm{NAD}^{+}$molecule processed. The ADP-ribose unit is subsequently connected to carboxyl groups in the target protein structure by glutamate, aspartate, lysine, arginine and serine residues $[27,85]$. When poly(ADP-ribose) (PAR) accumulates, it features a strong negatively charged nucleic-acid-like structure [86] and neutralizes positively charged groups, mediating chromatin de-condensation and stimulating transcription [81]. Among all the PARP1 functions, DNA methylation is not well understood yet. During carcinogenesis, major DNA methylation change happens globally and certain genes are targets of aberrant methylation, causing the epigenetic silencing of TSGs (Figure 3). However, a plausible mechanism published by [87] is that, after auto poly(ADP-ribosyl)ation of PARP1, poly(ADP-ribosyl)ated covalent chains recruit DNMT1 and block its catalytic activity, thus preventing aberrant hypermethylation. The mechanisms of DNMT1 recruitment and PARP1 activation at CpG islands remain unknown. Another study has later confirmed that PARP1 could directly impact DNA methylation patterns governing DNMT1 transcription and activity in mouse primordial germ cells via poly(ADP-ribosyl)ation [88]. Not only PARP1 poly(ADP ribosyl)ates DNMT1 to prevent its function and maintenance of methylation on newly formed DNA after replication [87], but the auto-poly(ribosyl)ation of PARP1 also facilitates DNMT1 expression by loosening chromatin or moving away from the DNA and providing access to transcription machinery [89]. In fact, there is a number of reports which shows that PARP1 binding to DNA sequences prevents DNA methylation and poly(ADP-ribosyl)ation has been indeed revealed to maintain the unmethylated status of regulatory zones of particular genes, including DNMT1, p16 (also known as p16INK4a, cyclin-dependent kinase inhibitor 2A), SMA (smooth muscle actin), THBD (thrombomodulin), TET1, the DMR1 (differentially methylated region 1) imprinted region, as well as certain other pluripotency-associated genes [89-97].

The epigenetic function of PARP1 has been revealed that it bookmarks the promoter of cell-identity genes during mitosis, which is crucial for expression of genes to survive daughter-cells survival when they enter into G1 [81,82]. It is possible, sequences of these promoters that remain to protect from methylation due to the presence of PARP1. In cancer cells, aberrant poly(ribosyl)ation activity or its controlling PARG activity disrupts DNA methylation; in some cases, it may be hyper- or hypomethylation depending on the cues that affect the poly(ribosyl)ation of DNMT1 [98]. Poly(ADP ribosyl)ation is reversible PARP1 enzymatic activity and PARG quickly maintains the homeostasis in the cell by degrading the PAR chain that prevents the disastrous effect on the cell. In PARG or homologous DNA-repair-defective cells, the enzymatic activity of PARP1 is increased and imbalances NAD homeostasis $[99,100]$. In case of excessive enzymatic activity, PARP1 poly(ADP ribosyl)ates itself and interacts with DNMT1 to form a complex and prevent DNMT1 functional activity to methylate DNA $[87,89,101]$. It leads to a scarcity of $\mathrm{NAD}^{+}$levels in cancer cells. It is a well-known fact that excessive PARP enzymatic activation causes a reduction in $\mathrm{NAD}^{+}$levels [102]. $\mathrm{NAD}^{+}$levels may decline to $20-30 \%$ of their previous levels under such circumstances, putting a rate limitation on the sirtuin enzymes [103]. The enzymatic activities of histone deacetylase (Sirtuins) largely reduce 
in these conditions because Sirtuins compete for NAD ${ }^{+}$with PARP1 [104-106] and this is followed by decreased SIRT1 expression [105]. Moreover, it may facilitate the transcription initiation of some oncogenes (responsible for cancer progression) by being unable to remove histone acetylation from already unmethylated genes (Figure 4). In this case, the use of the PARP1 inhibitor reverts all the functions to suppress the expression of oncogenes [102]. An increase in PARP1 enzymatic activity leads to inactivate DNMT1 enzymatically and causes hypomethylation on the promoter or downstream region of genes in normal cells (Figure 5).

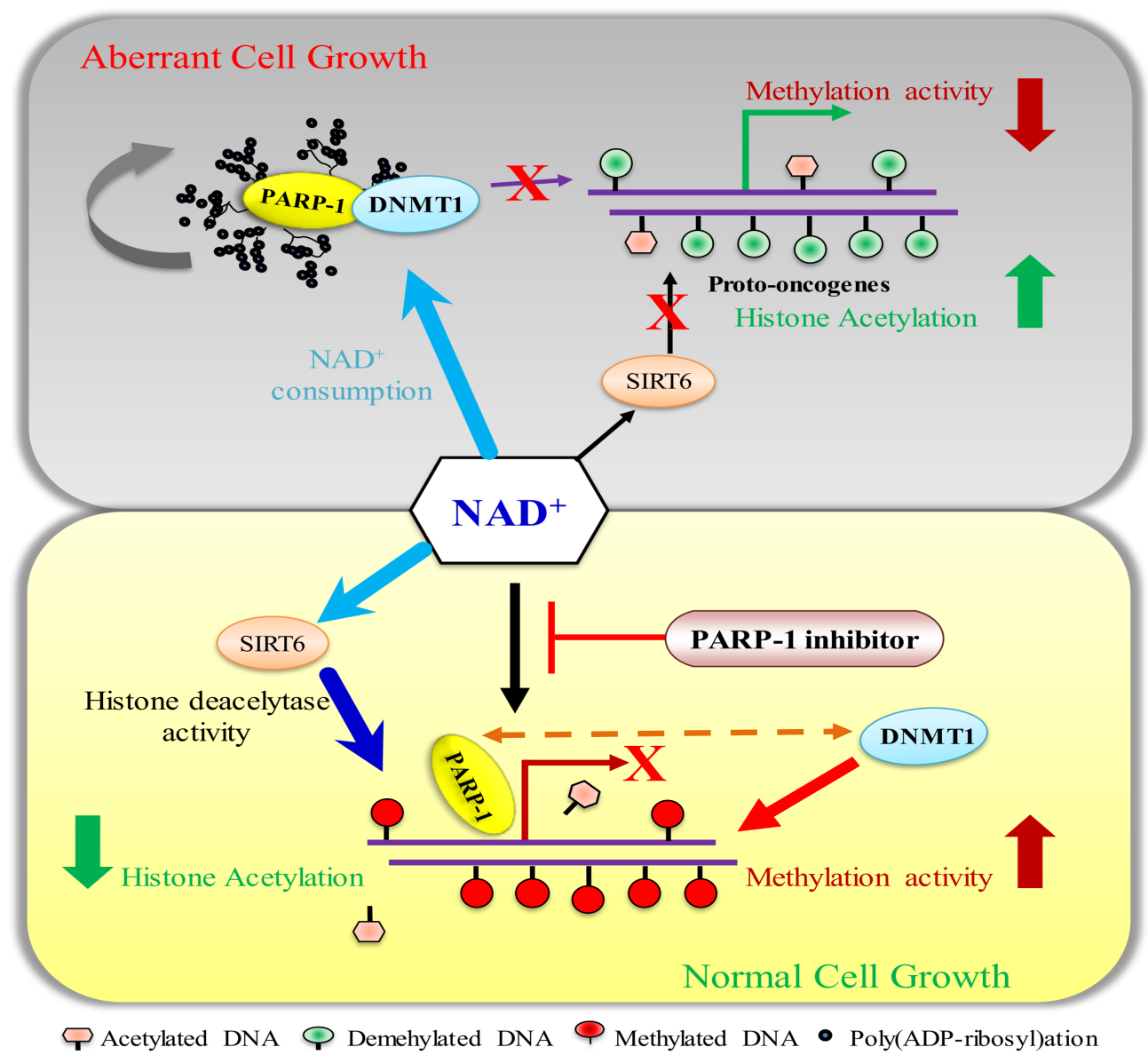

Figure 4. Increased poly(ADP-ribosyl)ation precludes DNMT1 and SIRT6 enzymatic activities. In cancer cells (prostate), the poly(ADP-ribosyl)ation pathway is severely disrupted, resulting in an enhanced activity that not only poly(ADP-ribosyl)ates PARP1 but also DNMT1; therefore, it prevents the maintenance of DNA methylation on newly synthesized DNA strands. Scarcity of NAD ${ }^{+}$ makes SIRT6 enzymatically inactive to remove the acetyl group from histone proteins, eventually facilitating the transcription of oncogenes. The PARP1 inhibitor reverts all activities, which leads to the suppression of oncogenes.

The silencing of the DNMT1 gene may be responsible for the global loss of methylation [87]. However, it opens other pathways to suppress genes by spreading heterochromatin (next section). DNA methylation dynamically changes in response to environmental cues, whereby DNA damages lead to the activation of DNA repair machinery and enzymatic activity of repair enzymes, including PARP1. PARP1 controls gene expression in two ways, i.e., (a) by binding to the upstream or downstream gene and (b) by performing the poly(ADP-ribosyl)ation of genes. These two pathways are contrasting; PARP1 provides access to transcription machinery after auto-poly(ADP-ribosyl)ation by leaving the binding sites of genes, such that genes become transcriptionally active. PARP1 localizes the DNMT1 promoter in normal cells [89], perhaps identifying and protecting unmethylated 
regions in the genome from methylation, thus contributing to the epigenetic control of gene expression [87].

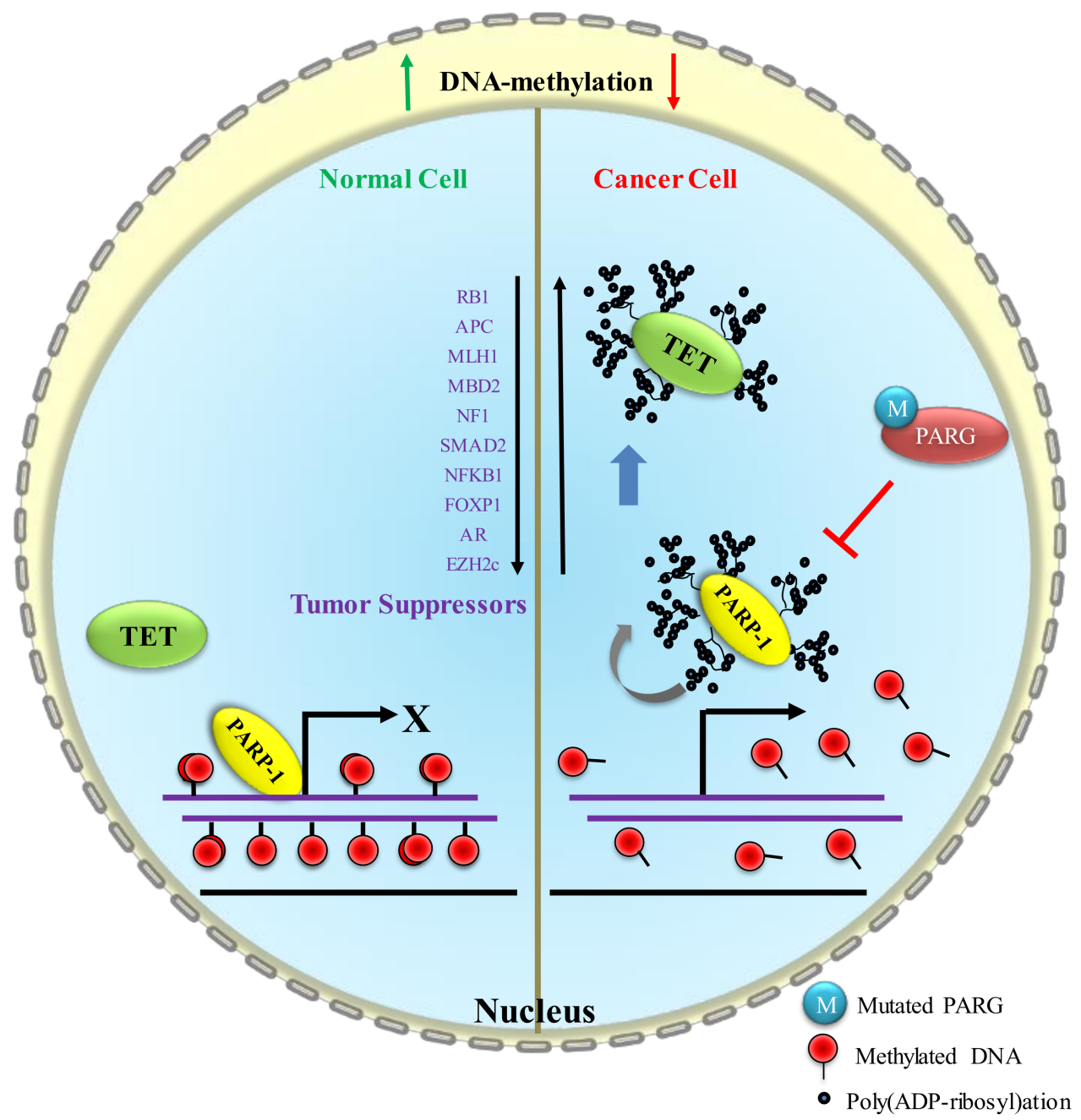

Figure 5. Enhanced poly(ADP-ribosyl)ation maintains DNA hypomethylation by activating TET1 functions. PARP1 binds to TSGs in their promoter region in normal cells. In PARG or homologous DNA-repair-defective cells, the enzymatic activity of PARP1 is increased (although TET1 activates PARP1 independently of DNA breaks) and poly(ADP-ribosyl)ated TET1 performs its DNA demethylation function. It leads DNA hypomethylation on the regulatory regions of genes in cancer cells. Eventually, it facilitates the expression of TSGs; although this is not quite straightforward in malignant cells, it is a model to understand the functional dependency of proteins to each other and it is helpful to develop therapies by taking advantage of them.

\section{PARP1 in DNA Hypermethylation and Its Effect on Cancer Progression}

TSGs are required for proper cell development because they halt cell division, correct DNA errors and regulate programmed cell death. TSGs that do not act correctly can cause cells to develop out of control, leading to cancer. Studies on retinoblastoma, a rare childhood eye tumor, have led to the discovery of the first TSG [107]. The cell needs of their respective pathways determine how these TSGs are expressed. Cancer cells, in particular, lose full control of all genes, including TSGs. TSG function is reduced in all malignancies by a variety of mechanisms, one of which is excessive DNA methylation. TET1 restores normalcy by reversing methylation. Excessive poly(ribosyl)ation activity in cancer cells poly(ADP-ribosyl)ates DNMT1 and renders its activity; TET1 is similarly poly(ADP ribosyl)ated, which is one of the causes of hypermethylation of DNA in these cells (Figure 6). 


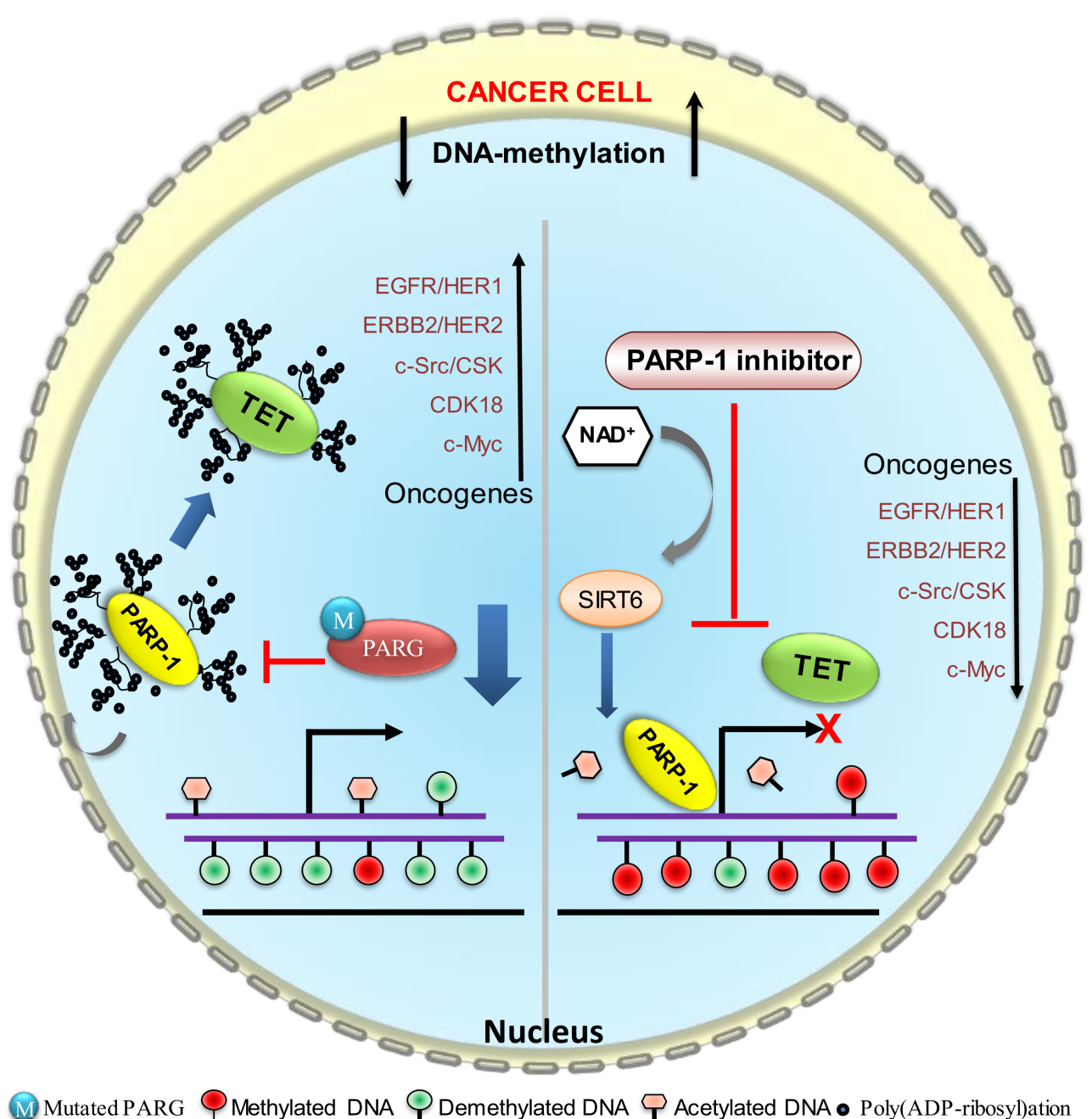

Figure 6. TET1 stimulates the activity of PARP1 independently of DNA damage. Poly(ADP-ribosyl)ation of TET1 by PARP1 increases TET1 enzymatic activity and regulates the hydroxylase activity of the DNA demethylation processes. Poly(ADP-ribosyl)ation of TET1 preserves the unmethylated state and activates the transcription of oncogenes. The PARP1 inhibitor inhibits the enzymatic activity of TET1, as a result, the expression of oncogenes is downregulated due to hypermethylation. Availability of $\mathrm{NAD}^{+}$makes SIRT6 enzymatically active to remove the acetyl group from histone proteins, further downregulating the transcription of oncogenes.

\subsection{Effect of DNA Hypermethylation on TSG (P53 and NF- $k B$ ) Expression}

1. P53, one of the major tumor suppressor proteins, and its loss of function by mutations or loss of expression cause more than $50 \%$ of human cancers. P53 also plays a key role in a multitude of DNA-damage response pathways [86]. It has been reported in several papers that P53 and PARP1 interact at multiple levels [108]. P53 is not only a covalent poly(ADP-ribosyl)ation target [109,110], but it also possesses a high-affinity noncovalent association with poly(ADP-ribosyl) [111]. Dysregulated poly(ribosyl)ation activity in cancer cells could be one of the possibilities to downregulate P53 expression via DNA hypermethylation on its gene region.

2. NF- $\mathrm{KB}$, the master regulator, mediates the crosstalk between cancer and inflammation at multiple levels. Enhanced NF- $k B$ function can cause pro-inflammatory cytokine production in tumor tissues, which significantly contributes to the pro-tumorigenic microenvironment [112].

In short, RelA/p65, RelB, c-Rel, p50 (NF-kB1) and p52 (NF-kB2) are members of the NF- $\mathrm{KB}$ transcription-factor family which exist as homo- and hetero-dimers (normally, 
NF- $\mathrm{B}$, p50 and p65) [113]. The composition of the dimer influences NF- $\mathrm{BB}$ enzyme stimulation, DNA-binding efficiency and DNA-sequence preference. In the absence of a signal, inhibitory proteins ( $\mathrm{I} \kappa \mathrm{B} \alpha, \beta$ or $\varepsilon$ ) interact with the dimers of NF- $\mathrm{kB}$ and segregate them in the cytoplasm [114]. The activation of the pathway causes the proteasomal degradation of inhibitors ( $\mathrm{I} \mathrm{B} \mathrm{B}, \beta$ or $\varepsilon$ ) [115], letting the NF- $\mathrm{kB}$ dimer enter the nucleus and trigger genes accountable for targeting cancer cells and pro-inflammatory transcription programs [116]. In response to a signal, PARP1 acts as a unique and essential transcriptional coactivator of NF- $\mathrm{KB}$ in vivo. PARP1's coactivator action is dependent on direct protein-protein interactions with both NF- $\mathrm{kB}$ subunits; extending PARP1 enzymatic activity plays a major and unique canonical transcriptional coactivatory role for NF- $\mathrm{KB}$-dependent gene regulation $[117,118]$. In AML cells, the NF- $\mathrm{kB}$ pathway is constitutively activated [119]. By binding to the promoter region of the PARP1 gene and regulating PARP1 gene transcription, RelA/p65 promotes DNA repair. PARP1 depletion decreases NF- $\mathrm{KB}$ function, suggesting that NF- $\mathrm{kB}$ and PARP1 form a DNA-repair positive feedback loop [120].

\subsection{Control of DNA Hypermethylation \\ DNA Methyltransferases Inhibitor}

Because TSG hypermethylation is a hallmark feature, much effort has gone into finding medicines that induce the DNA demethylation of these genes to restore their expression and function in cancer cells. Growing evidence suggests that inhibiting DNMTs is associated with decreased tumorigenicity and increased expression of TSGs. As a result, DNMTs are regarded as promising drug candidates for particular anti-cancer treatments. Nucleoside analogs decitabine, 5-Azacytidine and zebularine are the three most often used DNMT catalytic inhibitors, each with a distinct mode of action, discussed below. Several other subsequent generations of drugs have been discovered and checked for their role in cancer progression (Table 1).

\section{Decitabine}

In recent progress, DNA methylation has revealed its importance in the development of malignancies; this attracted attention, from the chemotherapeutic perspective, on the use of 5-Aza-2'-deoxycytidine (5-AZA-CdR, decitabine) for cancer treatment [121]. Decitabine (a DNA methyltransferase (DNMT) inhibitor approved by the FDA) is useful for the reduction in hematological neoplasms [122]. It transforms phosphorylated nucleotides into active forms, integrates DNA as a cytosine replacement, irreversibly binds to DNMTs and confines enzymes on DNA. As a result, the DNMT pool is depleted and its function is inhibited $[58,122]$. Decitabine at high micromolar dosages promptly causes DNA damage and cytotoxicity $[123,124]$. As previously stated, one of the most persistent signatures of malignancies is DNA hypermethylation on TSGs [125]. It leads to the loss of the regulated expression of TSGs that facilitates cancer cell growth [126-128].

Decitabine, an epigenetic drug that inhibits DNA methylation and has been licensed by the FDA, is being used to cure myelodysplastic syndrome (MDS). Several studies are in progress to treat acute myeloid leukemia (AML) and other malignancies. It helps to restore TSGs that have been silenced by abnormal DNA methylation, which is prevalent in all different cancers. It also suppresses DNMT3B expression, a de novo DNA methylating enzyme [129,130]. AML and MDS have been linked to DNMT3A mutations [131,132]. Both AML and MDS patients with these DNMT3A mutations have an unfavorable prognosis [133]. TNBC (triple-negative breast cancer) is a complex disease with poor survival. TNBC tumors have a lot of epigenetic biomarker genes with hypermethylated promoters. Decitabine treatment sensitizes TNBC cells that could be used for second-line treatment of chemoresistant patients [122,134]. However, only around $40 \%$ of Decitabine-treated AML patients eventually gain benefit from it and, even among responders, recurrence is common; these cells probably develop drug resistance due to adaptive pyrimidinemetabolism-network reactions [135]. 


\section{5-Azacytidine}

5-Azacytidine is a cytosine analog that has been found to promote DNA demethylation and is a powerful DNA methyltransferase inhibitor. Patients with higher-risk myelodysplastic syndrome (MDS) are treated with 5-azacytidine (Vidaza; Celgene Corporation, Boudry, Switzerland) [136]; it is also used for a subgroup of acute myeloid leukemia (AML) [137] and chronic myelomonocytic leukemia (CMML) patients [138]. By suppressing pancreaticductal-adenocarcinoma (PDAC) development in vivo, epigenetic reprogramming with 5-azacytidine induces an anti-cancer strategy in PDAC cells [139]. The de novo DNA methylating enzyme, DNMT3B, has been revealed to be inhibited by 5-azacytidine [129].

\section{Zebularine}

Zebularine is a nucleoside analog that, unlike 5 -azaC, is chemically stable and orally accessible. However, it can resolve Aza's shortcomings, including its cytotoxicity, instability and short half-life. Zebularine has been shown to inhibit DNMT in a variety of tissues in vitro and in vivo, including breast cancer, colorectal cancer, lung cancer and prostate cancer [140-144]. Zebularine can make tumor cells more chemosensitive and radiosensitive. Zebularine also possesses antimitotic and vascular inhibitory properties. For example, it stimulates the production of E-cadherin, a cellular gene that is typically suppressed by hypermethylation in malignancies [145]. Zebularine, in particular, has been shown to reactivate the silent $p 16$ gene and demethylate its promoter region in T24 bladder cancer cells [146].

Table 1. Recent update on DNMT inhibitors relatively to the regulation of the different types of cancer progression.

\begin{tabular}{|c|c|c|}
\hline DNMT Inhibitor & Effect on Cancer Progression & References \\
\hline Decitabine & $\begin{array}{c}\text { Lung Cancer, Colorectal Cancer, Breast Cancer, Prostate Cancer, Liver } \\
\text { Cancer, Acute Myeloid Leukemia }\end{array}$ & [147-152] \\
\hline 5-Azacitidine & $\begin{array}{c}\text { Gastric Cancer, Acute Myeloid Leukemia, Germ-Cell Tumor, Esophageal } \\
\text { Cancer, Colon Cancer }\end{array}$ & [153-159] \\
\hline Zebularine & $\begin{array}{c}\text { Colon Cancer, Liver Cancer, Pancreatic Cancer, Prostate Cancer, } \\
\text { Medulloblastoma }\end{array}$ & [140-144] \\
\hline Guadecitabine (SGI-110) & Germ-Cell Tumor, Ovarian Cancer, Liver Cancer, Urothelial Cancer & [160-163] \\
\hline 5-Fluro-2' deoxycytidine & Urothelial Cancer, Colon Cancer & {$[164,165]$} \\
\hline 5,6 , dihydro 5 azacytidine & T-Cell Acute Lymphocytic Leukemia, Acute Myeloid Leukemia & [166] \\
\hline CP-4200 & Acute Myeloid Leukemia, Breast Cancer, Colon Cancer & {$[167,168]$} \\
\hline Gemcitabine & Cervical Cancer, Colorectal Cancer, Pancreatic Cancer, Bladder Cancer & [169-174] \\
\hline $\mathrm{R} \times 3117$ & Pancreatic Cancer, Bladder Cancer, Lung Cancer, Leukemic Lymphoblasts & {$[175,176]$} \\
\hline Hydralazine & Prostate Cancer, Solid Cancers, Osteosarcoma & [177-179] \\
\hline
\end{tabular}

\section{PARP1 Inhibitors in DNA Hypomethylation of Cancer Cells}

\subsection{PARP1 Inhibitors}

The majority of PARP inhibitors are intended to challenge a binding site on the PARP1 molecule with nicotinamide adenine dinucleotide $\left(\mathrm{NAD}^{+}\right)$[180-186]. This approach led to the identification of NAD-like PARP inhibitors, which target not just PARP but also many other enzymatic pathways that use $\mathrm{NAD}^{+}$and other nucleotides as co-factors [25,187-189]. Using certain inhibitors has a negative impact on several $\mathrm{NAD}^{+} /$nucleotide-dependent enzymatic pathways, resulting in additional deleterious consequences caused by the silencing of other pathways, while the PARP1 pathway efficiency is reduced. As a result, the approach is to implement inhibitors based on PARP1's other functions [190-192].

Accumulating studies have suggested that the engagement of PARP1 with histone $4(\mathrm{H} 4)$ caused by DSBs activates PARP1 enzymatic activity and enhances Alt-NHEJ [26,193-196]. To overcome this obstacle, researchers have devised a new technique for blindly screening a small chemical library for PARP1 inhibitors by focusing on a very specific mechanism of PARP1 activation [197]. A collection of PARP1 inhibitors has been chosen based on this 
screen, along with their structural categorization. The search found structurally unique non-NAD-like inhibitors that block PARP1's role in cancer cells with better effectiveness and intensity than the conventional PARP1 inhibitors presently employed in treatments, besides drugs that exhibit structural similarities to $\mathrm{NAD}^{+}$or existing PARP1 inhibitors., Identification of 5F02, a non-NAD-like inhibitor blocks the H4-mediated activity of PARP1 but not PARP2 or Tankyrase-1, and tested successfully against a variety of cancer cells, including BRCA1-deficient breast cancer line (MDA-MB-43) [198-201]. Non-NAD-like PARP1 inhibitors have shown effectiveness in targeting androgen-dependent and -independent pathways of androgen-receptor-signaling activation, in comparison to NAD-like PARP1 inhibitors. It has been experimentally revealed that the presence of esters and methylation of quaternary ammonium salt is crucial for 5F02's anticancer action towards prostate-tumor growth [202]. In addition, researchers looked at the involvement of poly(ADP-ribose) glycohydrolase (PARG), a PARP1-related regulatory protein, in prostate carcinogenesis. According to the findings, PARG expression is significantly disrupted in prostate cancer cells (PC cells), which is linked to Cajal-body integrity and localization. Overall, the findings of our investigation support the use of non-NAD-like PARP1 inhibitors as a new therapeutic approach for progressive prostate cancer therapy [100]. PARP inhibitors use synthetic lethality to exploit homologous recombination (HR) deficiency and have emerged as potential anticancer medicines, particularly for BRCA1 or BRCA2 mutant carriers [203-205].

In Table 2, we summarize a list of significant PARP1 inhibitors, which are currently in clinical trials for different cancers, including prostate, breast, ovarian, liver cancers (solid) and lymphomas (non-Hodgkin).

Table 2. Clinical trials of PARP1 inhibitors.

\begin{tabular}{|c|c|c|}
\hline PARP1 Inhibitor & Cancer Type & NCT Number * \\
\hline Lynparza/Olaparib & $\begin{array}{c}\text { Ovarian Cancer } \\
\text { Breast Cancer }\end{array}$ & $\begin{array}{l}\text { NCT04041128 NCT04826198 } \\
\text { NCT04774406 NCT03462342 } \\
\text { NCT04065269 NCT03150576 } \\
\text { NCT04582552 NCT04774406 }\end{array}$ \\
\hline Cyh33 & $\begin{array}{c}\text { Ovarian Cancer } \\
\text { Breast Cancer } \\
\text { Solid Tumor } \\
\text { Prostate Cancer } \\
\text { Endometrial Cancer }\end{array}$ & NCT04586335 \\
\hline Talazoparib & $\begin{array}{c}\text { Neuroendocrine Tumors } \\
\text { Solid Tumor }\end{array}$ & NCT05053854 \\
\hline Rp12146 & $\begin{array}{c}\text { Lung Cancer } \\
\text { Breast Cancer } \\
\text { Ovarian Cancer }\end{array}$ & NCT05002868 \\
\hline Niraparib & $\begin{array}{c}\text { Advanced Solid Tumors } \\
\text { (Excluding Prostate Cancer) } \\
\text { Ovarian Cancer } \\
\text { Head And Neck Squamous } \\
\text { Cell Carcinoma }\end{array}$ & $\begin{array}{c}\text { NCT04267939 NCT04826198 } \\
\text { NCT04774406 NCT04734665 } \\
\text { NCT04681469 NCT04837209 } \\
\text { NCT04774406 }\end{array}$ \\
\hline Idx-1197 & Solid Tumors & NCT04174716 \\
\hline Talazoparib & Breast Cancer & $\begin{array}{l}\text { NCT03990896 } \\
\text { NCT04774406 }\end{array}$ \\
\hline Rucaparib & Solid Tumor & $\begin{array}{l}\text { NCT04276376 } \\
\text { NCT04774406 }\end{array}$ \\
\hline Veliparib & $\begin{array}{l}\text { Solid Tumors } \\
\text { Liver Tumors } \\
\text { Lymphomas } \\
\text { Prostate Cancer }\end{array}$ & $\begin{array}{l}\text { NCT01434316 } \\
\text { NCT01618357 }\end{array}$ \\
\hline
\end{tabular}

*These data were obtained from https://www.clinicaltrials.gov/ (accessed on 30 December 2021). NCT, National Clinical Trial number. 


\subsection{PARP1 Inhibitors in Reversal of Tumor-Suppressor-Gene Expression}

6.2.1. Increase in DNA Hypomethylation by an Increase in TET Activity

PARP inhibitors ablate the poly(ADP-ribosyl)ation of TET. The DNA-hypermethylationmediated silencing of TSGs is reversed by the inhibition of poly(ADP-ribosyl)ation activity of TET, thus enabling 5mC into 5HmC. Poly(ADP-ribosyl)ation stimulates TET1 enzymatic activity and TET1 activates PARP1 activity independently of DNA breaks (Figure 6) [101]. PARP activity positively regulates TET1 expression by maintaining the DNA hypomethylation of CpG islands and H3K4 trimethylation [101]. TET1 is abundantly expressed in T-ALL cells and is required for in vivo human T-ALL cell proliferation. TET1 enzymatic capability to demethylate DNA, which permits it to retain global 5-hydroxymethylcytosine (5hmC) marks. To regulate leukemic development, controlling the cell cycle, DNA-repair genes and T-ALL-related oncogenes are prerequisites. PARP1 enzymes, which are correlated with increased expression in T-ALL patients, interact with the TET1 promoter to help create $\mathrm{H} 3 \mathrm{~K} 4 \mathrm{me}^{3}$ modifications, thus accelerating transcription. TET1 expression that is dependent on PARP1 might be inhibited by PARP1 inhibitors such as Olaparib, resulting in the removal of $5 \mathrm{hmC}$ marks, which could lead to the development of a therapy route for T-ALL cells [206].

\subsubsection{Maintenance of DNA Methylation by Poly(ADP-ribosyl)ation of CTCF and DNMT1}

CTCF (CCCTC-binding factor) has been reported to be covalently poly(ADP-ribosyl)ated in vivo $[207,208]$. CTCF poly(ADP-ribosylation) inhibition stabilizes an upstream chromatin barrier and prevents neighboring heterochromatin from migrating into the active p16 tumor suppressor gene. In cancer development, the epigenetic inactivation of the p16INK4a tumor suppressor gene is a common target, which is an early marker in breast carcinogenesis. CTCF binds to this border and the absence of binding substantially correlates with p16 suppression in a variety of cancer cells [94,97]. CTCF binds to poly(ADPribosyl)ated PARP1 and DNMT1 unmethylated target sites, suggesting that PARP activity is essential to the maintenance of DNA methylation profiles. Loss of PARs, due to overexpression of PARG, results in the loss of CTCF and PARP1 DNA binding, as well as de novo methylation of CTCF-bound CpGs. These findings suggest that CTCF could contribute to the PARP-mediated safeguarding of certain DNA regions in their unmethylated form. Poly(ADP-ribosyl)ation, on the other hand, is accountable for maintaining the unmethylated condition of certain CTCF-bound CpGs. CTCF with PARP activity at its DNA target sites inhibits Dnmt1 functions, reducing de novo methylation of CpG dinucleotides. As a result of the de-repression of DNMT1 by deficient PARP activity, CTCF DNA targets are hypermethylated $[97,209,210]$.

\section{Combination Therapy of DNA Methyltransferase Inhibitor and PARP Inhibitor}

Cancers which are caused by compromised DNA-repair pathways are extremely sensitive to PARP1 inhibitors [116,211-213]. Acute myeloid leukemia (AML) is a heterogeneous cancer with a poor clinical prognosis. Previously, it has been reported that the BRCA1 expression level is reduced in AML samples [214]. When AML is addressed with DNA-damaging drugs or radiation therapy, BRCA1 activity is lost, leading to the accumulation of genomic abnormalities and cancer cell death [215]. Novel combinations of DNMTs and PARP inhibitors could enhance effectiveness; for example, AML patients which are resistant to chemotherapy are treated with a novel combination therapeutic strategy that is more effective when combined with decitabine (DNMT inhibitors) [216]. In addition to demethylating CpG-island gene-promoter regions, it increases poly (ADP-ribose) polymerase (PARP1) interaction to DNA and strong association to chromatin, limiting PARP-mediated DNA-repair or -transcription activation, thus downregulating HR DNA repair and making cancer cells more sensitive to the PARP inhibitor [217]. In AML patients, high PARP1 expression suggests poor survival. PARP inhibitors in association with histonedeacetylase inhibitors (SAHA-bendamustine hybrid) give a novel potential cure for AML. The combination effectively induces cell apoptosis and arrests the cancer cell cycle in the 
G2/M phase, thus delaying the development of AML and prolonging survival [206,218]. AML and acute lymphoblastic leukemia (ALL) have been both reported to have genomic alternations of PARP1 and compromised DNA-damage-response gene pathways. AML carries RUNX1-RUNX1T1 (transcription factor involved in the differentiation of hematopoietic stem cells into adult blood cells) fusion genes with functional deficiency in TET2 and DNMT3A genes [219], while TET1 is highly sensitive to PARP1 inhibitors in ALL patients, as shown in different clinical studies [206]. By reversion of mutations in BRCA1/2 genes, breastand ovarian-cancer cells become resistant to PARP inhibitors [220-222]. Previous studies have demonstrated that DNMT inhibitors re-sensitize the resistance of breast or ovarian cells to PARP inhibitors, independent of BRCA1/2 mutation status [223]. Importantly, these combinations of DNMT and PARP inhibitors suggest that there is a budding and open pathway to develop a therapy for other cancers which are not completely dependent on gene mutations in the DNA-damage-repair pathway. The TET2 gene is frequently mutated in malignant blood diseases (about $~ 50 \%$ in chronic myelomonocytic leukemia, CMML). In addition to demethylating genes, TET2 has a significant role in DNA repair pathways, either single-strand breaks (SSB) or double-strand breaks (DSB). TET2 knock-down causes a decrease in BRCA2 expression, which inhibits HR repair. In combination with a PARP inhibitor, both SSB and DSB are harmed, cell apoptosis is activated and cell survival is impeded [224].

\section{Perspective and Conclusions}

In recent studies on role of PARP1 in DNA dynamics, the extensive cross-talk between epigenetic pathways, including DNA methylation or demethylation and poly(ADPribosyl)ation of PARP1 itself or other target proteins, is evident. In cancer, both increases in and losses of DNA methylation are prevalent, but the processes that govern this methylation equilibrium are unknown. PARP1 plays a central role in DNA dynamics by enabling and executing DNMT1 or TET1 functions. Both proteins are functionally in contrast with each other, but their poly(ADP-ribosyl)ation depends on the enzymatical activation of PARP1 due to DNA damage in cancer cells or other cues. TET1 has been shown to trigger poly(ADP-ribosyl)ation independently of DNA damage to demethylate mouse primordial germ cells; this might be due to inhibitory DNMT1 activity or through the transcriptional up-regulation of the TET1 gene [88].

DNMT1 is a major protein in the hypermethylation of cancer cells [225,226]. In different cancers, the degree of poly(ADP-ribosyl)ation of PARP1 varies; it also depends on the role of the related regulatory protein known as PARG1 that reverses the PARP1 function by removing poly(ADP)ribose moieties from target proteins [227-229]. In prostate cancer, poly(ADP-ribosyl)ation activity has been observed to increase several folds due to PARG expression being severally disrupted in these cells [100]. However, the DNA methylation status of TSGs and their expression in these cells are not known. Sirtuin gene activities are also disrupted in these cells because of $\mathrm{NAD}^{+}$scarcity. It would be interesting to study the chromatin orchestration on TSGs and oncogenes in these cells with or without the use of PARP1 inhibitors. PARP1 inhibitors have been shown to be useful in the treatment of androgen-dependent malignancies [230-232].

Apart from inhibiting the enzymatic activity of DNMT1 by noncovalent poly(ADPribosyl)ation [87], poly(ADP-ribosyl)ated PARP1/ARTD1 positively controls DNMT1 expression [89]. Poly(ADP-ribosyl)ation of TET1 regulates transcriptional TET1 expression [93]. In contrast to hypermethylation, TNBC is one of the most hypomethylated cancers [233]. TET1 DNA demethylase is notably overexpressed in roughly $40 \%$ of patients [234]. PARP1 expression has been shown to be significantly increased in TNBC [235]. As a result, the US Food and Drug Administration (FDA) has approved two novel PARP inhibitors, Lynparza (olaparib) from AstraZeneca and Talzenna (talazoparib) from Pfizer, to manage metastatic TNBC patients with a BRCA (breast cancer type 1 susceptibility protein) mutation (or patients suspected to have one). 
PARP1 positively regulates the transcription of genes by auto poly(ADP-ribosyl)ation and negatively by inhibiting the enzymatic activity of target proteins by covalent modification. In other words, PARP1, by binding to promoter regions, suppresses the transcription of genes, while auto-poly(ribosy)lated PARP1 activates transcription by providing access to transcription factors [82,236]. Despite the multiple functions of PARP1 in terms of transcription and DNA methylation/demethylation, mice have been shown to grow normally under PARP1 knockout conditions [237], whereas it has been reported that double knockout PARP1/PARP2 mice died in early embryogenesis [238]. This suggests that there is redundancy in the function of the PARP gene family, although PARP1 alone poly-ribosylates $\sim 80-90 \%$ of target proteins [239].

DNA methylation is a dynamic and multi-regulated process; DNMT1 and TET1 are directly controlled and Poly(ADP-ribosyl)ation, PARP1, or PARG indirectly affects DNA methylation. In cancer, this tight regulation is disrupted by the increase or decrease in enzymatic activities and expression of these genes. In AML and breast cancer cells, DNA demethylating agents (DNMT inhibitors) improve the lethal action of PARP1 inhibitors [240-243]. Both inhibitors' synergistic impact enhances DNA damage and, as a result, tumor cytotoxicity [244,245]. Notably, this combined treatment method improves the PARP1 inhibitor potency in cancer cells. Furthermore, it may be used in the future as part of combination therapy for cancers in which the DNA-damage-repair mechanism is disrupted. The transcription reactivation of TSG $p 16$ is indirectly regulated by poly(ADP-ribosyl)ation of CTCF and the lack of binding substantially correlates with $p 16$ silence in a wide range of cancers [97]. This merging of the multiple functions of proteins is the research area in which the epigenetic role of poly(ADP-ribosyl)ation has become increasingly evident; not only it controls gene transcription/expression but it also affects their biological functions by affecting their enzymatic activities and modifying the respective pathways. Research in this direction would aid in obtaining a mechanistic understanding for governing the epigenetic dynamic alterations which drive biological and cellular processes, including development and differentiation, and an increased prevalence of illnesses.

Supplementary Materials: The following supporting information can be downloaded at: https: / / www.mdpi.com/article/10.3390/biom12030417/s1. Table S1. Dysregulation of DNMTs/TET in different types of cancer [246-274].

Author Contributions: R.S. and N.L. wrote the manuscript; N.L. and R.S. conceived the project, revised the text and finalized the manuscript, tables and figures. All authors have read and agreed to the published version of the manuscript.

Funding: This review received no external funding.

Institutional Review Board Statement: Not applicable.

Informed Consent Statement: Not applicable.

Data Availability Statement: Not applicable.

Acknowledgments: We appreciate the input of clinical colleagues and our lab members. We thank Rubi Singh for her critical revisions and suggestions. We apologize to our colleagues whose work could not be cited due to space constraints and we appreciate all the members of RS's Pandemic Response Laboratory (PRL), NY, and Weill Cornell Medicine, NY, for interactive discussions.

Conflicts of Interest: The authors declare no conflict of interest with respect to the authorship and publication of this article.

\section{References}

1. Boland, M.J.; Nazor, K.L.; Loring, J.F. Epigenetic regulation of pluripotency and differentiation. Circ. Res. 2014, 115, 311-324. [CrossRef] [PubMed]

2. Brookes, E.; Shi, Y. Diverse epigenetic mechanisms of human disease. Annu. Rev. Genet. 2014, 48, 237-268. [CrossRef]

3. Oh, E.S.; Petronis, A. Origins of human disease: The chrono-epigenetic perspective. Nat. Rev. Genet. 2021, 22, 533-546. [CrossRef] [PubMed] 
4. Reik, W.; Dean, W.; Walter, J. Epigenetic reprogramming in mammalian development. Science 2001, 293, 1089-1093. [CrossRef] [PubMed]

5. Bird, A. DNA methylation patterns and epigenetic memory. Genes Dev. 2002, 16, 6-21. [CrossRef] [PubMed]

6. Carlberg, C.; Molnár, F. DNA Methylation. In Human Epigenomics; Carlberg, C., Molnár, F., Eds.; Springer Singapore: Singapore, 2018; pp. 57-73.

7. Noroozi, R.; Ghafouri-Fard, S.; Pisarek, A.; Rudnicka, J.; Spolnicka, M.; Branicki, W.; Taheri, M.; Pospiech, E. DNA methylationbased age clocks: From age prediction to age reversion. Ageing Res. Rev. 2021, 68, 101314. [CrossRef]

8. Angeloni, A.; Bogdanovic, O. Sequence determinants, function, and evolution of CpG islands. Biochem. Soc. Trans. 2021, 49, 1109-1119. [CrossRef]

9. Kim, M.; Costello, J. DNA methylation: An epigenetic mark of cellular memory. Exp. Mol. Med. 2017, 49, e322. [CrossRef]

10. Skvortsova, K.; Stirzaker, C.; Taberlay, P. The DNA methylation landscape in cancer. Essays Biochem. 2019, 63, 797-811. [CrossRef]

11. Wilson, A.G. Epigenetic regulation of gene expression in the inflammatory response and relevance to common diseases. J. Periodontol 2008, 79, 1514-1519. [CrossRef]

12. Ng, H.H.; Zhang, Y.; Hendrich, B.; Johnson, C.A.; Turner, B.M.; Erdjument-Bromage, H.; Tempst, P.; Reinberg, D.; Bird, A. MBD2 is a transcriptional repressor belonging to the MeCP1 histone deacetylase complex. Nat. Genet. 1999, 23, 58-61. [CrossRef] [PubMed]

13. Suzuki, M.M.; Bird, A. DNA methylation landscapes: Provocative insights from epigenomics. Nat. Rev. Genet. 2008, 9, 465-476. [CrossRef] [PubMed]

14. Magaña-Acosta, M.; Valadez-Graham, V. Chromatin Remodelers in the 3D Nuclear Compartment. Front. Genet. 2020, 11, 600615. [CrossRef] [PubMed]

15. Fouse, S.D.; Nagarajan, R.O.; Costello, J.F. Genome-scale DNA methylation analysis. Epigenomics 2010, 2, 105-117. [CrossRef] [PubMed]

16. Tomizawa, S.; Kobayashi, H.; Watanabe, T.; Andrews, S.; Hata, K.; Kelsey, G.; Sasaki, H. Dynamic stage-specific changes in imprinted differentially methylated regions during early mammalian development and prevalence of non-CpG methylation in oocytes. Development 2011, 138, 811-820. [CrossRef]

17. Lister, R.; Mukamel, E.A.; Nery, J.R.; Urich, M.; Puddifoot, C.A.; Johnson, N.D.; Lucero, J.; Huang, Y.; Dwork, A.J.; Schultz, M.D.; et al. Global epigenomic reconfiguration during mammalian brain development. Science 2013, 341, 1237905. [CrossRef]

18. Guo, J.U.; Su, Y.; Shin, J.H.; Shin, J.; Li, H.; Xie, B.; Zhong, C.; Hu, S.; Le, T.; Fan, G.; et al. Distribution, recognition and regulation of non-CpG methylation in the adult mammalian brain. Nat. Neurosci. 2014, 17, 215-222. [CrossRef]

19. Ramsahoye, B.H.; Biniszkiewicz, D.; Lyko, F.; Clark, V.; Bird, A.P.; Jaenisch, R. Non-CpG methylation is prevalent in embryonic stem cells and may be mediated by DNA methyltransferase 3a. Proc. Natl. Acad. Sci. USA 2000, 97, 5237-5242. [CrossRef]

20. Stoccoro, A.; Coppede, F. Mitochondrial DNA Methylation and Human Diseases. Int. J. Mol. Sci. 2021, 22, 4594. [CrossRef]

21. Srivastava, R.; Ahn, S.H. Modifications of RNA polymerase II CTD: Connections to the histone code and cellular function. Biotechnol. Adv. 2015, 33, 856-872. [CrossRef]

22. Srivastava, R.; Duan, R.; Ahn, S.H. Multiple roles of CTDK-I throughout the cell. Cell Mol. Life Sci. 2019, 76, 2789-2797. [CrossRef]

23. Srivastava, R.; Singh, U.M.; Dubey, N.K. Histone Modifications by different histone modifiers: Insights into histone writers and erasers during chromatin modification. J. Biol. Sci. Med. 2016, 2, 45-54.

24. Srivastava, R.; Srivastava, R.; Ahn, S.H. The Epigenetic Pathways to Ribosomal DNA Silencing. Microbiol. Mol. Biol. Rev. 2016, 80, 545-563. [CrossRef] [PubMed]

25. van Beek, L.; McClay, E.; Patel, S.; Schimpl, M.; Spagnolo, L.; de Oliveira, T.M. PARP Power: A Structural Perspective on PARP1, PARP2, and PARP3 in DNA Damage Repair and Nucleosome Remodelling. Int. J. Mol. Sci. 2021, 22, 5112. [CrossRef] [PubMed]

26. Spiegel, J.O.; Van Houten, B.; Durrant, J.D. PARP1: Structural insights and pharmacological targets for inhibition. DNA Repair 2021, 103, 103125. [CrossRef] [PubMed]

27. Ummarino, S.; Hausman, C.; Di Ruscio, A. The PARP Way to Epigenetic Changes. Genes 2021, 12, 446. [CrossRef]

28. Tulin, A.; Spradling, A. Chromatin loosening by poly(ADP)-ribose polymerase (PARP) at Drosophila puff loci. Science 2003, $299,560-562$. [CrossRef]

29. Titcombe, P.; Murray, R.; Hewitt, M.; Antoun, E.; Cooper, C.; Inskip, H.M.; Holbrook, J.D.; Godfrey, K.M.; Lillycrop, K.; Hanson, M.; et al. Human non-CpG methylation patterns display both tissue-specific and inter-individual differences suggestive of underlying function. Epigenetics 2021, 1-12. [CrossRef]

30. Rideout, W.M., 3rd; Coetzee, G.A.; Olumi, A.F.; Jones, P.A. 5-Methylcytosine as an endogenous mutagen in the human LDL receptor and p53 genes. Science 1990, 249, 1288-1290. [CrossRef]

31. Stadler, M.B.; Murr, R.; Burger, L.; Ivanek, R.; Lienert, F.; Schöler, A.; van Nimwegen, E.; Wirbelauer, C.; Oakeley, E.J.; Gaidatzis, D.; et al. DNA-binding factors shape the mouse methylome at distal regulatory regions. Nature 2011, 480, 490-495. [CrossRef]

32. Aran, D.; Sabato, S.; Hellman, A. DNA methylation of distal regulatory sites characterizes dysregulation of cancer genes. Genome Biol. 2013, 14, R21. [CrossRef] [PubMed]

33. Papin, C.; Le Gras, S.; Ibrahim, A.; Salem, H.; Karimi, M.M.; Stoll, I.; Ugrinova, I.; Schröder, M.; Fontaine-Pelletier, E.; Omran, Z.; et al. CpG Islands Shape the Epigenome Landscape. J. Mol. Biol. 2021, 433, 166659. [CrossRef] [PubMed]

34. Lee, J.T.; Bartolomei, M.S. X-inactivation, imprinting, and long noncoding RNAs in health and disease. Cell 2013, 152, 1308-1323. [CrossRef] [PubMed]

35. Bestor, T.H. The DNA methyltransferases of mammals. Hum. Mol. Genet. 2000, 9, 2395-2402. [CrossRef]

36. Greenberg, M.V.C.; Bourc'his, D. The diverse roles of DNA methylation in mammalian development and disease. Nat. Rev. Mol. Cell Biol. 2019, 20, 590-607. [CrossRef] 
37. Arand, J.; Spieler, D.; Karius, T.; Branco, M.R.; Meilinger, D.; Meissner, A.; Jenuwein, T.; Xu, G.; Leonhardt, H.; Wolf, V.; et al. In vivo control of CpG and non-CpG DNA methylation by DNA methyltransferases. PLoS Genet. 2012, 8, e1002750. [CrossRef]

38. Day, J.J.; Kennedy, A.J.; Sweatt, J.D. DNA methylation and its implications and accessibility for neuropsychiatric therapeutics. Annu. Rev. Pharm. Toxicol. 2015, 55, 591-611. [CrossRef]

39. Chen, Z.X.; Riggs, A.D. DNA methylation and demethylation in mammals. J. Biol. Chem. 2011, 286, 18347-18353. [CrossRef]

40. Auclair, G.; Weber, M. Mechanisms of DNA methylation and demethylation in mammals. Biochimie 2012, 94, 2202-2211. [CrossRef]

41. Okano, M.; Bell, D.W.; Haber, D.A.; Li, E. DNA methyltransferases Dnmt3a and Dnmt3b are essential for de novo methylation and mammalian development. Cell 1999, 99, 247-257. [CrossRef]

42. Chen, T.; Ueda, Y.; Dodge, J.E.; Wang, Z.; Li, E. Establishment and maintenance of genomic methylation patterns in mouse embryonic stem cells by Dnmt3a and Dnmt3b. Mol. Cell Biol. 2003, 23, 5594-5605. [CrossRef] [PubMed]

43. Liang, G.; Chan, M.F.; Tomigahara, Y.; Tsai, Y.C.; Gonzales, F.A.; Li, E.; Laird, P.W.; Jones, P.A. Cooperativity between DNA methyltransferases in the maintenance methylation of repetitive elements. Mol. Cell. Biol. 2002, 22, 480-491. [CrossRef] [PubMed]

44. Zeng, Y.; Chen, T. DNA Methylation Reprogramming during Mammalian Development. Genes 2019, 10, 257. [CrossRef] [PubMed]

45. Kareta, M.S.; Botello, Z.M.; Ennis, J.J.; Chou, C.; Chedin, F. Reconstitution and mechanism of the stimulation of de novo methylation by human DNMT3L. J. Biol. Chem. 2006, 281, 25893-25902. [CrossRef] [PubMed]

46. Ooi, S.K.; Wolf, D.; Hartung, O.; Agarwal, S.; Daley, G.Q.; Goff, S.P.; Bestor, T.H. Dynamic instability of genomic methylation patterns in pluripotent stem cells. Epigenetics Chromatin. 2010, 3, 17. [CrossRef]

47. Bourc'his, D.; Xu, G.L.; Lin, C.S.; Bollman, B.; Bestor, T.H. Dnmt3L and the establishment of maternal genomic imprints. Science 2001, 294, 2536-2539. [CrossRef]

48. Chedin, F. The DNMT3 family of mammalian de novo DNA methyltransferases. Prog. Mol. Biol. Transl. Sci. 2011, 101, 255-285. [CrossRef]

49. Hu, Y.G.; Hirasawa, R.; Hu, J.L.; Hata, K.; Li, C.L.; Jin, Y.; Chen, T.P.; Li, E.; Rigolet, M.; Viegas-Pequignot, E.; et al. Regulation of DNA methylation activity through Dnmt3L promoter methylation by Dnmt3 enzymes in embryonic development. Hum. Mol. Genet. 2008, 17, 2654-2664. [CrossRef]

50. Gujar, H.; Weisenberger, D.J.; Liang, G. The Roles of Human DNA Methyltransferases and Their Isoforms in Shaping the Epigenome. Genes 2019, 10, 172. [CrossRef]

51. Neri, F.; Krepelova, A.; Incarnato, D.; Maldotti, M.; Parlato, C.; Galvagni, F.; Matarese, F.; Stunnenberg, H.G.; Oliviero, S. Dnmt3L antagonizes DNA methylation at bivalent promoters and favors DNA methylation at gene bodies in ESCs. Cell 2013, 155, 121-134. [CrossRef]

52. Meng, H.; Cao, Y.; Qin, J.; Song, X.; Zhang, Q.; Shi, Y.; Cao, L. DNA methylation, its mediators and genome integrity. Int. J. Biol. Sci. 2015, 11, 604-617. [CrossRef] [PubMed]

53. Goll, M.G.; Bestor, T.H. Eukaryotic cytosine methyltransferases. Annu. Rev. Biochem. 2005, 74, 481-514. [CrossRef] [PubMed]

54. Goll, M.G.; Kirpekar, F.; Maggert, K.A.; Yoder, J.A.; Hsieh, C.L.; Zhang, X.; Golic, K.G.; Jacobsen, S.E.; Bestor, T.H. Methylation of tRNAAsp by the DNA methyltransferase homolog Dnmt2. Science 2006, 311, 395-398. [CrossRef]

55. Zhang, Y.; Zhang, X.; Shi, J.; Tuorto, F.; Li, X.; Liu, Y.; Liebers, R.; Zhang, L.; Qu, Y.; Qian, J.; et al. Dnmt2 mediates intergenerational transmission of paternally acquired metabolic disorders through sperm small non-coding RNAs. Nat. Cell Biol. 2018, 20, 535-540. [CrossRef]

56. Rasmussen, K.D.; Helin, K. Role of TET enzymes in DNA methylation, development, and cancer. Genes Dev. 2016, 30, 733-750. [CrossRef] [PubMed]

57. Kohli, R.M.; Zhang, Y. TET enzymes, TDG and the dynamics of DNA demethylation. Nature 2013, 502, 472-479. [CrossRef]

58. Jones, P.A.; Taylor, S.M. Cellular differentiation, cytidine analogs and DNA methylation. Cell 1980, 20, 85-93. [CrossRef]

59. Mayer, W.; Niveleau, A.; Walter, J.; Fundele, R.; Haaf, T. Demethylation of the zygotic paternal genome. Nature 2000, 403, 501-502. [CrossRef]

60. An, J.; Rao, A.; Ko, M. TET family dioxygenases and DNA demethylation in stem cells and cancers. Exp. Mol. Med. 2017, 49, e323. [CrossRef]

61. Melamed, P.; Yosefzon, Y.; David, C.; Tsukerman, A.; Pnueli, L. Tet Enzymes, Variants, and Differential Effects on Function. Front. Cell Dev. Biol. 2018, 6, 22. [CrossRef]

62. Dick, A.; Chen, A. The role of TET proteins in stress-induced neuroepigenetic and behavioural adaptations. Neurobiol. Stress 2021, 15, 100352. [CrossRef] [PubMed]

63. Neri, F.; Incarnato, D.; Oliviero, S. DNA methylation and demethylation dynamics. Oncotarget 2015, 6, 34049-34050. [CrossRef] [PubMed]

64. Nawy, T. Dynamics of DNA demethylation. Nat. Methods 2013, 10, 466. [CrossRef] [PubMed]

65. Bhutani, N.; Burns, D.M.; Blau, H.M. DNA demethylation dynamics. Cell 2011, 146, 866-872. [CrossRef]

66. Pastor, W.A.; Aravind, L.; Rao, A. TETonic shift: Biological roles of TET proteins in DNA demethylation and transcription. Nat. Rev. Mol. Cell Biol. 2013, 14, 341-356. [CrossRef]

67. Jin, S.G.; Zhang, Z.M.; Dunwell, T.L.; Harter, M.R.; Wu, X.; Johnson, J.; Li, Z.; Liu, J.; Szabó, P.E.; Lu, Q.; et al. Tet3 Reads 5Carboxylcytosine through Its CXXC Domain and Is a Potential Guardian against Neurodegeneration. Cell Rep. 2016, 14, 493-505. [CrossRef]

68. Valencia, A.M.; Kadoch, C. Chromatin regulatory mechanisms and therapeutic opportunities in cancer. Nat. Cell Biol. 2019, $21,152-161$. [CrossRef] 
69. Zhang, J.; Yang, C.; Wu, C.; Cui, W.; Wang, L. DNA Methyltransferases in Cancer: Biology, Paradox, Aberrations, and Targeted Therapy. Cancers 2020, 12, 2123. [CrossRef]

70. Lakshminarasimhan, R.; Liang, G. The Role of DNA Methylation in Cancer. Adv. Exp. Med. Biol. 2016, 945, 151-172. [CrossRef]

71. Gao, J.; Wang, L.; Xu, J.; Zheng, J.; Man, X.; Wu, H.; Jin, J.; Wang, K.; Xiao, H.; Li, S.; et al. Aberrant DNA methyltransferase expression in pancreatic ductal adenocarcinoma development and progression. J. Exp. Clin. Cancer Res. 2013, 32, 86. [CrossRef]

72. Han, M.; Jia, L.; Lv, W.; Wang, L.; Cui, W. Epigenetic Enzyme Mutations: Role in Tumorigenesis and Molecular Inhibitors. Front. Oncol. 2019, 9, 194. [CrossRef] [PubMed]

73. Jung, H.; Kim, H.S.; Kim, J.Y.; Sun, J.M.; Ahn, J.S.; Ahn, M.J.; Park, K.; Esteller, M.; Lee, S.H.; Choi, J.K. DNA methylation loss promotes immune evasion of tumours with high mutation and copy number load. Nat. Commun. 2019, 10, 4278. [CrossRef] [PubMed]

74. Sheaffer, K.L.; Elliott, E.N.; Kaestner, K.H. DNA Hypomethylation Contributes to Genomic Instability and Intestinal Cancer Initiation. Cancer Prev. Res. 2016, 9, 534-546. [CrossRef] [PubMed]

75. Cao, J.; Yan, Q. Cancer Epigenetics, Tumor Immunity, and Immunotherapy. Trends Cancer 2020, 6, 580-592. [CrossRef] [PubMed]

76. Yue, X.; Rao, A. TET family dioxygenases and the TET activator vitamin C in immune responses and cancer. Blood 2020, 136, 1394-1401. [CrossRef] [PubMed]

77. Kamaletdinova, T.; Fanaei-Kahrani, Z.; Wang, Z.Q. The Enigmatic Function of PARP1: From PARylation Activity to PAR Readers Cells 2019, 8, 1625. [CrossRef]

78. Kotova, E.; Lodhi, N.; Jarnik, M.; Pinnola, A.D.; Ji, Y.; Tulin, A.V. Drosophila histone H2A variant (H2Av) controls poly(ADP-ribose) polymerase 1 (PARP1) activation in chromatin. Proc. Natl. Acad. Sci. USA 2011, 108, 6205-6210. [CrossRef]

79. Ji, Y.; Thomas, C.; Tulin, N.; Lodhi, N.; Boamah, E.; Kolenko, V.; Tulin, A.V. Charon Mediates Immune Deficiency-Driven PARP-1-Dependent Immune Responses in Drosophila. J. Immunol. 2016, 197, 2382-2389. [CrossRef]

80. Boamah, E.K.; Kotova, E.; Garabedian, M.; Jarnik, M.; Tulin, A.V. Poly(ADP-Ribose) polymerase 1 (PARP-1) regulates ribosomal biogenesis in Drosophila nucleoli. PLoS Genet. 2012, 8, e1002442. [CrossRef]

81. Lodhi, N.; Ji, Y.; Tulin, A. Mitotic bookmarking: Maintaining post-mitotic reprogramming of transcription reactivation. Curr. Mol. Biol. Rep. 2016, 2, 10-16. [CrossRef]

82. Lodhi, N.; Kossenkov, A.V.; Tulin, A.V. Bookmarking promoters in mitotic chromatin: Poly(ADP-ribose)polymerase-1 as an epigenetic mark. Nucleic Acids Res. 2014, 42, 7028-7038. [CrossRef] [PubMed]

83. Zardo, G.; DErme, M.; Reale, A.; Strom, R.; Perilli, M.; Caiafa, P. Does poly(ADP-ribosyl)ation regulate the DNA methylation pattern? Biochemistry 1997, 36, 7937-7943. [CrossRef] [PubMed]

84. Zardo, G.; Marenzi, S.; Perilli, M.; Caiafa, P. Inhibition of poly(ADP-ribosyl)ation introduces an anomalous methylation pattern in transfected foreign DNA. FASEB J. 1999, 13, 1518-1522. [CrossRef] [PubMed]

85. Kraus, W.L.; Hottiger, M.O. PARP-1 and gene regulation: Progress and puzzles. Mol. Asp. Med. 2013, 34, 1109-1123. [CrossRef] [PubMed]

86. Fischbach, A.; Krüger, A.; Hampp, S.; Assmann, G.; Rank, L.; Hufnagel, M.; Stöckl, M.T.; Fischer, J.M.F.; Veith, S.; Rossatti, P.; et al. The C-terminal domain of p53 orchestrates the interplay between non-covalent and covalent poly(ADP-ribosyl)ation of p53 by PARP1. Nucleic Acids Res. 2018, 46, 804-822. [CrossRef]

87. Reale, A.; Matteis, G.D.; Galleazzi, G.; Zampieri, M.; Caiafa, P. Modulation of DNMT1 activity by ADP-ribose polymers. Oncogene 2005, 24, 13-19. [CrossRef]

88. Ciccarone, F.; Klinger, F.G.; Catizone, A.; Calabrese, R.; Zampieri, M.; Bacalini, M.G.; De Felici, M.; Caiafa, P. Poly(ADPribosyl)ation Acts in the DNA Demethylation of Mouse Primordial Germ Cells Also with DNA Damage-Independent Roles. PLOS ONE 2012, 7, e46927. [CrossRef]

89. Zampieri, M.; Passananti, C.; Calabrese, R.; Perilli, M.; Corbi, N.; De Cave, F.; Guastafierro, T.; Bacalini, M.G.; Reale, A.; Amicosante, G.; et al. Parp1 localizes within the Dnmt1 promoter and protects its unmethylated state by its enzymatic activity. PLoS ONE 2009, 4, e4717. [CrossRef]

90. Ciccarone, F.; Zampieri, M.; Caiafa, P. PARP1 orchestrates epigenetic events setting up chromatin domains. Semin. Cell Dev. Biol. 2017, 63, 123-134. [CrossRef]

91. Nocchi, L.; Tomasetti, M.; Amati, M.; Neuzil, J.; Santarelli, L.; Saccucci, F. Thrombomodulin Is Silenced in Malignant Mesothelioma by a Poly(ADP-ribose) Polymerase-1-mediated Epigenetic Mechanism. J. Biol. Chem. 2011, 286, 19478-19488. [CrossRef]

92. Hu, B.; Wu, Z.; Hergert, P.; Henke, C.A.; Bitterman, P.B.; Phan, S.H. Regulation of Myofibroblast Differentiation by Poly(ADPRibose) Polymerase 1. Am. J. Pathol. 2013, 182, 71-83. [CrossRef] [PubMed]

93. Ciccarone, F.; Valentini, E.; Bacalini, M.G.; Zampieri, M.; Calabrese, R.; Guastafierro, T.; Mariano, G.; Reale, A.; Franceschi, C.; Caiafa, P. Poly(ADP-ribosyl)ation is involved in the epigenetic control of TET1 gene transcription. Oncotarget 2014, 5, 10356-10367. [CrossRef] [PubMed]

94. Zampieri, M.; Guastafierro, T.; Calabrese, R.; Ciccarone, F.; Bacalini, M.G.; Reale, A.; Perilli, M.; Passananti, C.; Caiafa, P. ADP-ribose polymers localized on Ctcf-Parp1-Dnmt1 complex prevent methylation of Ctcf target sites. Biochem. J. 2012, 441, 645-652. [CrossRef] [PubMed]

95. Doege, C.A.; Inoue, K.; Yamashita, T.; Rhee, D.B.; Travis, S.; Fujita, R.; Guarnieri, P.; Bhagat, G.; Vanti, W.B.; Shih, A.; et al. Early-stage epigenetic modification during somatic cell reprogramming by Parp1 and Tet2. Nature 2012, 488, 652-655. [CrossRef]

96. Roper, S.J.; Chrysanthou, S.; Senner, C.E.; Sienerth, A.; Gnan, S.; Murray, A.; Masutani, M.; Latos, P.; Hemberger, M. ADPribosyltransferases Parp1 and Parp7 safeguard pluripotency of ES cells. Nucleic Acids Res. 2014, 42, 8914-8927. [CrossRef] 
97. Witcher, M.; Emerson, B.M. Epigenetic Silencing of the p16INK4a Tumor Suppressor Is Associated with Loss of CTCF Binding and a Chromatin Boundary. Mol. Cell 2009, 34, 271-284. [CrossRef]

98. Kulis, M.; Esteller, M. DNA methylation and cancer. Adv. Genet. 2010, 70, 27-56. [CrossRef]

99. Gottipati, P.; Vischioni, B.; Schultz, N.; Solomons, J.; Bryant, H.E.; Djureinovic, T.; Issaeva, N.; Sleeth, K.; Sharma, R.A.; Helleday, T. Poly(ADP-ribose) polymerase is hyperactivated in homologous recombination-defective cells. Cancer Res. 2010, 70, 5389-5398. [CrossRef]

100. Karpova, Y.; Wu, C.; Divan, A.; McDonnell, M.E.; Hewlett, E.; Makhov, P.; Gordon, J.; Ye, M.; Reitz, A.B.; Childers, W.E.; et al Non-NAD-like PARP-1 inhibitors in prostate cancer treatment. Biochem. Pharm. 2019, 167, 149-162. [CrossRef]

101. Ciccarone, F.; Valentini, E.; Zampieri, M.; Caiafa, P. 5mC-hydroxylase activity is influenced by the PARylation of TET1 enzyme. Oncotarget 2015, 6, 24333-24347. [CrossRef]

102. Berger, N.A. Poly(ADP-ribose) in the cellular response to DNA damage. Radiat. Res. 1985, 101, 4-15. [CrossRef] [PubMed]

103. Houtkooper, R.H.; Canto, C.; Wanders, R.J.; Auwerx, J. The secret life of NAD+: An old metabolite controlling new metabolic signaling pathways. Endocr. Rev. 2010, 31, 194-223. [CrossRef] [PubMed]

104. Pillai, J.B.; Gupta, M.; Rajamohan, S.B.; Lang, R.; Raman, J.; Gupta, M.P. Poly(ADP-ribose) polymerase-1-deficient mice are protected from angiotensin II-induced cardiac hypertrophy. Am. J. Physiol Heart Circ. Physiol. 2006, 291, H1545-H1553. [CrossRef] [PubMed]

105. Qin, W.D.; Wei, S.J.; Wang, X.P.; Wang, J.; Wang, W.K.; Liu, F.; Gong, L.; Yan, F.; Zhang, Y.; Zhang, M. Poly(ADP-ribose) polymerase 1 inhibition protects against low shear stress induced inflammation. Biochim. Biophys. Acta 2013, 1833, 59-68. [CrossRef]

106. Rajamohan, S.B.; Pillai, V.B.; Gupta, M.; Sundaresan, N.R.; Birukov, K.G.; Samant, S.; Hottiger, M.O.; Gupta, M.P. SIRT1 promotes cell survival under stress by deacetylation-dependent deactivation of poly(ADP-ribose) polymerase 1. Mol. Cell Biol. 2009, 29, 4116-4129. [CrossRef]

107. Aerts, I.; Lumbroso-Le Rouic, L.; Gauthier-Villars, M.; Brisse, H.; Doz, F.; Desjardins, L. Retinoblastoma. Orphanet J. Rare Dis. 2006, 1, 31. [CrossRef]

108. Wesierska-Gadek, J.; Wojciechowski, J.; Schmid, G. Central and carboxy-terminal regions of human p53 protein are essential for interaction and complex formation with PARP-1. J. Cell Biochem. 2003, 89, 220-232. [CrossRef]

109. Simbulan-Rosenthal, C.M.; Rosenthal, D.S.; Luo, R.; Smulson, M.E. Poly(ADP-ribosyl)ation of p53 during apoptosis in human osteosarcoma cells. Cancer Res. 1999, 59, 2190-2194.

110. Ayyappan, V.; Wat, R.; Barber, C.; Vivelo, C.A.; Gauch, K.; Visanpattanasin, P.; Cook, G.; Sazeides, C.; Leung, A.K.L. ADPriboDB 2.0: An updated database of ADP-ribosylated proteins. Nucleic Acids Res. 2021, 49, D261-D265. [CrossRef]

111. Malanga, M.; Pleschke, J.M.; Kleczkowska, H.E.; Althaus, F.R. Poly(ADP-ribose) binds to specific domains of p53 and alters its DNA binding functions. J. Biol Chem. 1998, 273, 11839-11843. [CrossRef]

112. Xia, Y.; Shen, S.; Verma, I.M. NF-kappaB, an active player in human cancers. Cancer Immunol. Res. 2014, 2, 823-830. [CrossRef] [PubMed]

113. Baldwin, A.S., Jr. The NF-kappa B and I kappa B proteins: New discoveries and insights. Annu. Rev. Immunol. 1996, 14, 649-683. [CrossRef] [PubMed]

114. Karin, M.; Delhase, M. The I kappa B kinase (IKK) and NF-kappa B: Key elements of proinflammatory signalling. Semin. Immunol. 2000, 12, 85-98. [CrossRef] [PubMed]

115. Karin, M.; Ben-Neriah, Y. Phosphorylation meets ubiquitination: The control of NF-[kappa]B activity. Annu. Rev. Immunol. 2000, 18, 621-663. [CrossRef]

116. Weaver, A.N.; Yang, E.S. Beyond DNA Repair: Additional Functions of PARP-1 in Cancer. Front. Oncol. 2013, 3, 290. [CrossRef]

117. Hassa, P.O.; Covic, M.; Hasan, S.; Imhof, R.; Hottiger, M.O. The enzymatic and DNA binding activity of PARP-1 are not required for NF-kappa B coactivator function. J. Biol. Chem. 2001, 276, 45588-45597. [CrossRef]

118. Le Page, C.; Sanceau, J.; Drapier, J.C.; Wietzerbin, J. Inhibitors of ADP-ribosylation impair inducible nitric oxide synthase gene transcription through inhibition of NF kappa B activation. Biochem. Biophys. Res. Commun. 1998, 243, 451-457. [CrossRef]

119. Kagoya, Y.; Yoshimi, A.; Kataoka, K.; Nakagawa, M.; Kumano, K.; Arai, S.; Kobayashi, H.; Saito, T.; Iwakura, Y.; Kurokawa, M. Positive feedback between NF-KB and TNF- $\alpha$ promotes leukemia-initiating cell capacity. J. Clin. Investig. 2014, 124, 528-542. [CrossRef]

120. Li, D.; Luo, Y.; Chen, X.; Zhang, L.; Wang, T.; Zhuang, Y.; Fan, Y.; Xu, J.; Chen, Y.; Wu, L. NF-kB and Poly (ADP-ribose) Polymerase 1 Form a Positive Feedback Loop that Regulates DNA Repair in Acute Myeloid Leukemia Cells. Mol. Cancer Res. 2019, 17, 761-772. [CrossRef]

121. Jones, P.A.; Baylin, S.B. The fundamental role of epigenetic events in cancer. Nat. Rev. Genet. 2002, 3, 415-428. [CrossRef]

122. Yu, J.; Qin, B.; Moyer, A.M.; Nowsheen, S.; Liu, T.; Qin, S.; Zhuang, Y.; Liu, D.; Lu, S.W.; Kalari, K.R.; et al. DNA methyltransferase expression in triple-negative breast cancer predicts sensitivity to decitabine. J. Clin. Investig. 2018, 128, 2376-2388. [CrossRef] [PubMed]

123. Christman, J.K. 5-Azacytidine and 5-aza-2'-deoxycytidine as inhibitors of DNA methylation: Mechanistic studies and their implications for cancer therapy. Oncogene 2002, 21, 5483-5495. [CrossRef] [PubMed]

124. Jüttermann, R.; Li, E.; Jaenisch, R. Toxicity of 5-aza-2'-deoxycytidine to mammalian cells is mediated primarily by covalent trapping of DNA methyltransferase rather than DNA demethylation. Proc. Natl. Acad. Sci. USA 1994, 91, 11797-11801. [CrossRef]

125. Esteller, M. Relevance of DNA methylation in the management of cancer. Lancet Oncol. 2003, 4, 351-358. [CrossRef] 
126. Sakai, T.; Toguchida, J.; Ohtani, N.; Yandell, D.W.; Rapaport, J.M.; Dryja, T.P. Allele-specific hypermethylation of the retinoblastoma tumor-suppressor gene. Am. J. Hum. Genet. 1991, 48, 880-888. [PubMed]

127. Herman, J.G.; Latif, F.; Weng, Y.; Lerman, M.I.; Zbar, B.; Liu, S.; Samid, D.; Duan, D.S.; Gnarra, J.R.; Linehan, W.M.; et al. Silencing of the VHL tumor-suppressor gene by DNA methylation in renal carcinoma. Proc. Natl. Acad. Sci. USA 1994, 91, 9700-9704. [CrossRef] [PubMed]

128. Esteller, M. Cancer epigenomics: DNA methylomes and histone-modification maps. Nat. Rev. Genet. 2007, 8, 286-298. [CrossRef] [PubMed]

129. Hagemann, S.; Heil, O.; Lyko, F.; Brueckner, B. Azacytidine and Decitabine Induce Gene-Specific and Non-Random DNA Demethylation in Human Cancer Cell Lines. PLoS ONE 2011, 6, e17388. [CrossRef]

130. Schneider-Stock, R.; Diab-Assef, M.; Rohrbeck, A.; Foltzer-Jourdainne, C.; Boltze, C.; Hartig, R.; Schönfeld, P.; Roessner, A.; Gali-Muhtasib, H. 5-aza-Cytidine Is a Potent Inhibitor of DNA Methyltransferase 3a and Induces Apoptosis in HCT-116 Colon Cancer Cells via Gadd45- and p53-Dependent Mechanisms. J. Pharmacol. Exp. Ther. 2005, 312, 525-536. [CrossRef]

131. Ley, T.J.; Ding, L.; Walter, M.J.; McLellan, M.D.; Lamprecht, T.; Larson, D.E.; Kandoth, C.; Payton, J.E.; Baty, J.; Welch, J.; et al. DNMT3A mutations in acute myeloid leukemia. N. Engl. J. Med. 2010, 363, 2424-2433. [CrossRef]

132. Walter, M.J.; Ding, L.; Shen, D.; Shao, J.; Grillot, M.; McLellan, M.; Fulton, R.; Schmidt, H.; Kalicki-Veizer, J.; O'Laughlin, M.; et al Recurrent DNMT3A mutations in patients with myelodysplastic syndromes. Leukemia 2011, 25, 1153-1158. [CrossRef] [PubMed]

133. Oka, M.; Meacham, A.M.; Hamazaki, T.; Rodic, N.; Chang, L.J.; Terada, N. De novo DNA methyltransferases Dnmt3a and Dnmt3b primarily mediate the cytotoxic effect of 5-aza-2'-deoxycytidine. Oncogene 2005, 24, 3091-3099. [CrossRef] [PubMed]

134. Bennett, G.; Brown, A.; Mudd, G.; Huxley, P.; Van Rietschoten, K.; Pavan, S.; Chen, L.; Watcham, S.; Lahdenranta, J.; Keen, N. MMAE Delivery Using the Bicycle Toxin Conjugate BT5528. Mol. Cancer Ther. 2020, 19, 1385-1394. [CrossRef] [PubMed]

135. Gu, X.; Tohme, R.; Tomlinson, B.; Sakre, N.; Hasipek, M.; Durkin, L.; Schuerger, C.; Grabowski, D.; Zidan, A.M.; Radivoyevitch, T.; et al. Decitabine- and 5-azacytidine resistance emerges from adaptive responses of the pyrimidine metabolism network. Leukemia 2021, 35, 1023-1036. [CrossRef] [PubMed]

136. Silverman, L.R.; Demakos, E.P.; Peterson, B.L.; Kornblith, A.B.; Holland, J.C.; Odchimar-Reissig, R.; Stone, R.M.; Nelson, D.; Powell, B.L.; DeCastro, C.M.; et al. Randomized controlled trial of azacitidine in patients with the myelodysplastic syndrome: A study of the cancer and leukemia group B. J. Clin. Oncol. 2002, 20, 2429-2440. [CrossRef]

137. Fenaux, P.; Mufti, G.J.; Hellström-Lindberg, E.; Santini, V.; Gattermann, N.; Germing, U.; Sanz, G.; List, A.F.; Gore, S.; Seymour, J.F.; et al Azacitidine prolongs overall survival compared with conventional care regimens in elderly patients with low bone marrow blast count acute myeloid leukemia. J. Clin. Oncol. 2010, 28, 562-569. [CrossRef]

138. Adès, L.; Sekeres, M.A.; Wolfromm, A.; Teichman, M.L.; Tiu, R.V.; Itzykson, R.; Maciejewski, J.P.; Dreyfus, F.; List, A.F.; Fenaux, P.; et al. Predictive factors of response and survival among chronic myelomonocytic leukemia patients treated with azacitidine. Leuk. Res. 2013, 37, 609-613. [CrossRef]

139. Campbell, K.J.; Dhayade, S.; Ferrari, N.; Sims, A.H.; Johnson, E.; Mason, S.M.; Dickson, A.; Ryan, K.M.; Kalna, G.; Edwards, J.; et al. MCL-1 is a prognostic indicator and drug target in breast cancer. Cell Death Dis. 2018, 9, 19. [CrossRef]

140. Sabatino, M.A.; Geroni, C.; Ganzinelli, M.; Ceruti, R.; Broggini, M. Zebularine partially reverses GST methylation in prostate cancer cells and restores sensitivity to the DNA minor groove binder brostallicin. Epigenetics 2013, 8, 656-665. [CrossRef]

141. Sanaei, M.; Kavoosi, F.; Behjoo, H. Effect of valproic acid and zebularine on SOCS-1 and SOCS-3 gene expression in colon carcinoma SW48 cell line. Exp. Oncol. 2020, 42, 183-187. [CrossRef]

142. Sanaei, M.; Kavoosi, F.; Hosseini, F. Effect of Zebularine on p16INK4a, p14ARF, p15INK4b, and DNA Methyltransferase 1 Gene Expression, Cell Growth Inhibition, and Apoptosis Induction in Human Hepatocellular Carcinoma PLC/PRF5 and Pancreatic Cancer PA-TU-8902 Cell Lines. Iran. J. Pharm. Res. IJPR 2020, 19, 193-202. [CrossRef] [PubMed]

143. Andrade, A.F.; Borges, K.S.; Suazo, V.K.; Geron, L.; Corrêa, C.A.; Castro-Gamero, A.M.; de Vasconcelos, E.J.; de Oliveira, R.S.; Neder, L.; Yunes, J.A.; et al. The DNA methyltransferase inhibitor zebularine exerts antitumor effects and reveals BATF2 as a poor prognostic marker for childhood medulloblastoma. Investig. New Drugs 2017, 35, 26-36. [CrossRef] [PubMed]

144. Wang, Q.; Liang, N.; Yang, T.; Li, Y.; Li, J.; Huang, Q.; Wu, C.; Sun, L.; Zhou, X.; Cheng, X.; et al. DNMT1-mediated methylation of BEX1 regulates stemness and tumorigenicity in liver cancer. J. Hepatol. 2021, 75, 1142-1153. [CrossRef] [PubMed]

145. Chen, B.-S. Constructing host/pathogen genetic-and-epigenetic networks for investigating molecular mechanisms to identify drug targets in the infection of Epstein-Barr virus via big data mining and genome-wide NGS data identification. In Systems Immunology and Infection Microbiology, 1st ed.; Academic Press: Salt Lake City, UT, USA, 2021; pp. 489-557.

146. Cheng, J.C.; Matsen, C.B.; Gonzales, F.A.; Ye, W.; Greer, S.; Marquez, V.E.; Jones, P.A.; Selker, E.U. Inhibition of DNA Methylation and Reactivation of Silenced Genes by Zebularine. JNCI J. Natl. Cancer Inst. 2003, 95, 399-409. [CrossRef]

147. Momparler, R.L.; Ayoub, J. Potential of 5-aza-2'-deoxycytidine (Decitabine) a potent inhibitor of DNA methylation for therapy of advanced non-small cell lung cancer. Lung Cancer 2001, 34 (Suppl. 4), S111-S115. [CrossRef]

148. Bu, F.; Zhu, X.; Liu, S.; Lin, K.; Zhu, J.; Huang, J. Comprehensive analysis of Syk gene methylation in colorectal cancer. Immun. Inflamm. Dis. 2021, 9, 923-931. [CrossRef]

149. Bévant, K.; Desoteux, M.; Abdel Wahab, A.H.A.; Abdel Wahab, S.A.; Metwally, A.M.; Coulouarn, C. DNA Methylation of TGF $\beta$ Target Genes: Epigenetic Control of TGF $\beta$ Functional Duality in Liver Cancer. Cells 2021, 10, 2207. [CrossRef] 
150. Buocikova, V.; Longhin, E.M.; Pilalis, E.; Mastrokalou, C.; Miklikova, S.; Cihova, M.; Poturnayova, A.; Mackova, K.; Babelova, A.; Trnkova, L.; et al. Decitabine potentiates efficacy of doxorubicin in a preclinical trastuzumab-resistant HER2-positive breast cancer models. Biomed. Pharm. 2022, 147, 112662. [CrossRef]

151. Su, Y.; Huang, Q.; Lu, L.; Qu, H.; Wang, D.; Qiu, J.; Li, W.; Lin, M.; Liu, H.; Wang, Z.; et al. Promoter Methylation-Mediated NPTX2 Silencing Promotes Tumor Growth in Human Prostate Cancer. J. Cancer 2022, 13, 706-714. [CrossRef]

152. Wang, P.; Zhang, L.W.; Lu, C.Q.; Wang, T.Z.; Shan, M.; Xiao, J.Y.; Tian, H.; Ma, X.; Xu, Y.; Wu, D.P. Efficacy and safety of venetoclax combined with azacitidine versus CAG regimen combined with decitabine in elderly patients with relapsed acute myeloid leukemia. Zhonghua Nei Ke Za Zhi 2022, 61, 157-163. [CrossRef]

153. El Khawanky, N.; Hughes, A.; Yu, W.; Myburgh, R.; Matschulla, T.; Taromi, S.; Aumann, K.; Clarson, J.; Vinnakota, J.M.; Shoumariyeh, K.; et al. Demethylating therapy increases anti-CD123 CAR T cell cytotoxicity against acute myeloid leukemia. Nat. Commun. 2021, 12, 6436. [CrossRef] [PubMed]

154. Jin, S.; Cojocari, D.; Purkal, J.J.; Popovic, R.; Talaty, N.N.; Xiao, Y.; Solomon, L.R.; Boghaert, E.R.; Leverson, J.D.; Phillips, D.C. 5-Azacitidine Induces NOXA to Pri.ime AML Cells for Venetoclax-Mediated Apoptosis. Clin. Cancer Res. 2020, 26, $3371-3383$. [CrossRef] [PubMed]

155. Rezaei, S.; Hosseinpourfeizi, M.A.; Moaddab, Y.; Safaralizadeh, R. Contribution of DNA methylation and EZH2 in SRBC down-regulation in gastric cancer. Mol. Biol. Rep. 2020, 47, 5721-5727. [CrossRef] [PubMed]

156. Chan, A.T.; Tao, Q.; Robertson, K.D.; Flinn, I.W.; Mann, R.B.; Klencke, B.; Kwan, W.H.; Leung, T.W.; Johnson, P.J.; Ambinder, R.F. Azacitidine induces demethylation of the Epstein-Barr virus genome in tumors. J. Clin. Oncol. 2004, 22, 1373-1381. [CrossRef]

157. Oing, C.; Verem, I.; Mansour, W.Y.; Bokemeyer, C.; Dyshlovoy, S.; Honecker, F. 5-Azacitidine Exerts Prolonged Pro-Apoptotic Effects and Overcomes Cisplatin-Resistance in Non-Seminomatous Germ Cell Tumor Cells. Int. J. Mol. Sci. 2018, 20, 21. [CrossRef] [PubMed]

158. Schneider, B.J.; Shah, M.A.; Klute, K.; Ocean, A.; Popa, E.; Altorki, N.; Lieberman, M.; Schreiner, A.; Yantiss, R.; Christos, P.J.; et al. Phase I Study of Epigenetic Priming with Azacitidine Prior to Standard Neoadjuvant Chemotherapy for Patients with Resectable Gastric and Esophageal Adenocarcinoma: Evidence of Tumor Hypomethylation as an Indicator of Major Histopathologic Response. Clin. Cancer Res. 2017, 23, 2673-2680. [CrossRef] [PubMed]

159. Desai, N.; Sajed, D.; Arora, K.S.; Solovyov, A.; Rajurkar, M.; Bledsoe, J.R.; Sil, S.; Amri, R.; Tai, E.; MacKenzie, O.C.; et al. Diverse repetitive element RNA expression defines epigenetic and immunologic features of colon cancer. JCI Insight 2017, 2, e91078. [CrossRef]

160. Fang, F.; Munck, J.; Tang, J.; Taverna, P.; Wang, Y.; Miller, D.F.; Pilrose, J.; Choy, G.; Azab, M.; Pawelczak, K.S.; et al. The novel, small-molecule DNA methylation inhibitor SGI-110 as an ovarian cancer chemosensitizer. Clin. Cancer Res. 2014, 20, 6504-6516. [CrossRef]

161. Hernández-Oliveras, A.; Izquierdo-Torres, E.; Hernández-Martínez, G.; Zarain-Herzberg, Á.; Santiago-García, J. Transcriptional and epigenetic landscape of $\mathrm{Ca}(2+)$-signaling genes in hepatocellular carcinoma. J. Cell Commun. Signal. 2021, 15, 433-445. [CrossRef]

162. Crabb, S.J.; Danson, S.; Catto, J.W.F.; Hussain, S.; Chan, D.; Dunkley, D.; Downs, N.; Marwood, E.; Day, L.; Saunders, G.; et al. Phase I Trial of DNA Methyltransferase Inhibitor Guadecitabine Combined with Cisplatin and Gemcitabine for Solid Malignancies Including Urothelial Carcinoma (SPIRE). Clin. Cancer Res. 2021, 27, 1882-1892. [CrossRef]

163. Albany, C.; Fazal, Z.; Singh, R.; Bikorimana, E.; Adra, N.; Hanna, N.H.; Einhorn, L.H.; Perkins, S.M.; Sandusky, G.E.; Christensen, B.C.; et al. A phase 1 study of combined guadecitabine and cisplatin in platinum refractory germ cell cancer. Cancer Med. 2021, 10, 156-163. [CrossRef] [PubMed]

164. Zhao, Q.; Fan, J.; Hong, W.; Li, L.; Wu, M. Inhibition of cancer cell proliferation by 5-fluoro-2'-deoxycytidine, a DNA methylation inhibitor, through activation of DNA damage response pathway. SpringerPlus 2012, 1, 65. [CrossRef] [PubMed]

165. Coyne, G.O.S.; Wang, L.; Zlott, J.; Juwara, L.; Covey, J.M.; Beumer, J.H.; Cristea, M.C.; Newman, E.M.; Koehler, S.; Nieva, J.J.; et al. Intravenous 5-fluoro-2'-deoxycytidine administered with tetrahydrouridine increases the proportion of p16-expressing circulating tumor cells in patients with advanced solid tumors. Cancer Chemother. Pharm. 2020, 85, 979-993. [CrossRef] [PubMed]

166. Matoušová, M.; Votruba, I.; Otmar, M.; Tloušt'ová, E.; Günterová, J.; Mertlíková-Kaiserová, H. 2'-deoxy-5,6-dihydro-5-azacytidinea less toxic alternative of 2'-deoxy-5-azacytidine. Epigenetics 2011, 6, 769-776. [CrossRef] [PubMed]

167. Hummel-Eisenbeiss, J.; Hascher, A.; Hals, P.A.; Sandvold, M.L.; Müller-Tidow, C.; Lyko, F.; Rius, M. The role of human equilibrative nucleoside transporter 1 on the cellular transport of the DNA methyltransferase inhibitors 5-azacytidine and CP-4200 in human leukemia cells. Mol. Pharmacol. 2013, 84, 438-450. [CrossRef]

168. Brueckner, B.; Rius, M.; Markelova, M.R.; Fichtner, I.; Hals, P.-A.; Sandvold, M.L.; Lyko, F. Delivery of 5-Azacytidine to Human Cancer Cells by Elaidic Acid Esterification Increases Therapeutic Drug Efficacy. Mol. Cancer Ther. 2010, 9, 1256-1264. [CrossRef]

169. Candelaria, M.; de la Cruz-Hernandez, E.; Taja-Chayeb, L.; Perez-Cardenas, E.; Trejo-Becerril, C.; Gonzalez-Fierro, A.; Chavez-Blanco, A.; Soto-Reyes, E.; Dominguez, G.; Trujillo, J.E.; et al. DNA methylation-independent reversion of gemcitabine resistance by hydralazine in cervical cancer cells. PLoS ONE 2012, 7, e29181. [CrossRef]

170. Lu, C.; Yang, D.; Sabbatini, M.E.; Colby, A.H.; Grinstaff, M.W.; Oberlies, N.H.; Pearce, C.; Liu, K. Contrasting roles of H3K4me3 and $\mathrm{H} 3 \mathrm{~K} 9 \mathrm{me} 3$ in regulation of apoptosis and gemcitabine resistance in human pancreatic cancer cells. BMC Cancer 2018, 18, 149. [CrossRef] 
171. Gu, Y.; Zhang, B.; Gu, G.; Yang, X.; Qian, Z. Metformin increases the chemosensitivity of pancreatic cancer cells to gemcitabine by reversing EMT through regulation DNA methylation of miR-663. OncoTargets Ther. 2020, 13, 10417. [CrossRef]

172. Stubbe, B.E.; Henriksen, S.D.; Madsen, P.H.; Larsen, A.C.; Krarup, H.B.; Pedersen, I.S.; Johansen, M.N.; Thorlacius-Ussing, O Validation of SFRP1 Promoter Hypermethylation in Plasma as a Prognostic Marker for Survival and Gemcitabine Effectiveness in Patients with Stage IV Pancreatic Adenocarcinoma. Cancers 2021, 13, 5717. [CrossRef]

173. Baretti, M.; Karunasena, E.; Zahurak, M.; Walker, R.; Zhao, Y.; Pisanic, T.R., 2nd; Wang, T.-H.; Greten, T.F.; Duffy, A.G.; Gootjes, E.; et al. A phase 2 trial of gemcitabine and docetaxel in patients with metastatic colorectal adenocarcinoma with methylated checkpoint with forkhead and ring finger domain promoter and/or microsatellite instability phenotype. Clin. Transl. Sci. 2021, 14, 954-963. [CrossRef] [PubMed]

174. Yoshino, H.; Enokida, H.; Osako, Y.; Nohata, N.; Yonemori, M.; Sugita, S.; Kuroshima, K.; Tsuruda, M.; Tatarano, S.; Nakagawa, M. Characterization of PHGDH expression in bladder cancer: Potential targeting therapy with gemcitabine/cisplatin and the contribution of promoter DNA hypomethylation. Mol. Oncol. 2020, 14, 2190-2202. [CrossRef] [PubMed]

175. Honeywell, R.J.; Sarkisjan, D.; Kristensen, M.H.; de Klerk, D.J.; Peters, G.J. DNA methyltransferases expression in normal tissues and various human cancer cell lines, xenografts and tumors. Nucleosides Nucleotides Nucleic Acids 2018, 37, 696-708. [CrossRef] [PubMed]

176. Sarkisjan, D.; Julsing, J.R.; El Hassouni, B.; Honeywell, R.J.; Kathmann, I.; Matherly, L.H.; Lee, Y.B.; Kim, D.J.; Peters, G.J RX-3117 (Fluorocyclopentenyl-Cytosine)-Mediated Down-Regulation of DNA Methyltransferase 1 Leads to Protein Expression of Tumor-Suppressor Genes and Increased Functionality of the Proton-Coupled Folate Carrier. Int. J. Mol. Sci. 2020, $21,2717$. [CrossRef] [PubMed]

177. Lopes, N.; Pacheco, M.B.; Soares-Fernandes, D.; Correia, M.P.; Camilo, V.; Henrique, R.; Jerónimo, C. Hydralazine and Enzalutamide: Synergistic Partners against Prostate Cancer. Biomedicines 2021, 9, 976. [CrossRef]

178. Bauman, J.; Shaheen, M.; Verschraegen, C.F.; Belinsky, S.A.; Houman Fekrazad, M.; Lee, F.-C.; Rabinowitz, I.; Ravindranathan, M.; Jones, D.V. A Phase I Protocol of Hydralazine and Valproic Acid in Advanced, Previously Treated Solid Cancers. Transl. Oncol. 2014, 7, 349-354. [CrossRef]

179. Kumanishi, S.; Yamanegi, K.; Nishiura, H.; Fujihara, Y.; Kobayashi, K.; Nakasho, K.; Futani, H.; Yoshiya, S. Epigenetic modulators hydralazine and sodium valproate act synergistically in VEGI-mediated anti-angiogenesis and VEGF interference in human osteosarcoma and vascular endothelial cells. Int. J. Oncol 2019, 55, 167-178. [CrossRef]

180. Murai, J.; Huang, S.Y.; Das, B.B.; Renaud, A.; Zhang, Y.; Doroshow, J.H.; Ji, J.; Takeda, S.; Pommier, Y. Trapping of PARP1 and PARP2 by Clinical PARP Inhibitors. Cancer Res. 2012, 72, 5588-5599. [CrossRef]

181. Choi, W.; Lee, E.S. Therapeutic Targ.geting of DNA Damage Response in Cancer. Int. J. Mol. Sci. 2022, 23, 1701. [CrossRef]

182. Hanna, D.; Chopra, N.; Hochhauser, D.; Khan, K. The role of PARP inhibitors in gastrointestinal cancers. Crit. Rev. Oncol. 2022, 171, 103621. [CrossRef]

183. Li, F.; Wu, X.; Fu, X.; Liu, J.; Song, W.; Xiao, G.G.; Lu, A.; Zhang, G. Poly (ADP-ribose) polymerase 1 (PARP1) inhibition promotes pulmonary metastasis of osteosarcoma by boosting ezrin phosphorylation. Int. J. Biol. Sci. 2022, 18, 1238-1253. [CrossRef] [PubMed]

184. Sha, H.; Gan, Y.; Zou, R.; Wu, J.; Feng, J. Research Advances in the Role of the Poly ADP Ribose Polymerase Family in Cancer Front. Oncol. 2021, 11, 790967. [CrossRef] [PubMed]

185. Wang, Y.; Zheng, K.; Xiong, H.; Huang, Y.; Chen, X.; Zhou, Y.; Qin, W.; Su, J.; Chen, R.; Qiu, H.; et al. PARP Inhibitor Upregulates PD-L1 Expression and Provides a New Combination Therapy in Pancreatic Cancer. Front. Immunol. 2021, 12, 762989. [CrossRef] [PubMed]

186. Wei, L.; Wang, M.; Wang, Q.; Han, Z. Dual targeting, a new strategy for novel PARP inhibitor discovery. Drug Discov. Ther. 2021, 15, 300-309. [CrossRef]

187. Alemasova, E.E.; Lavrik, O.I. Poly(ADP-ribosyl)ation by PARP1: Reaction mechanism and regulatory proteins. Nucleic Acids Res. 2019, 47, 3811-3827. [CrossRef]

188. Kim, C.; Chen, C.; Yu, Y. Avoid the trap: Targeting PARP1 beyond human malignancy. Cell Chem. Biol. 2021, 28, 456-462. [CrossRef]

189. Martínez-Morcillo, F.J.; Cantón-Sandoval, J.; Martínez-Menchón, T.; Corbalán-Vélez, R.; Mesa-Del-Castillo, P.; Pérez-Oliva, A.B.; García-Moreno, D.; Mulero, V. Non-canonical roles of NAMPT and PARP in inflammation. Dev. Comp. Immunol. 2021, 115, 103881. [CrossRef]

190. Biegała, Ł.; Gajek, A.; Marczak, A.; Rogalska, A. PARP inhibitor resistance in ovarian cancer: Underlying mechanisms and therapeutic approaches targeting the ATR/CHK1 pathway. Biochim. Biophys. Acta. 2021, 1876, 188633. [CrossRef]

191. Kim, D.S.; Camacho, C.V.; Kraus, W.L. Alternate therapeutic pathways for PARP inhibitors and potential mechanisms of resistance. Exp. Mol. Med. 2021, 53, 42-51. [CrossRef]

192. Ngoi, N.Y.L.; Leo, E.; O'Connor, M.J.; Yap, T.A. Development of Next-Generation Poly(ADP-Ribose) Polymerase 1-Selective Inhibitors. Cancer J. 2021, 27, 521-528. [CrossRef]

193. Bird, A.W.; Yu, D.Y.; Pray-Grant, M.G.; Qiu, Q.; Harmon, K.E.; Megee, P.C.; Grant, P.A.; Smith, M.M.; Christman, M.F. Acetylation of histone H4 by Esa1 is required for DNA double-strand break repair. Nature 2002, 419, 411-415. [CrossRef] [PubMed]

194. Thomas, C.J.; Kotova, E.; Andrake, M.; Adolf-Bryfogle, J.; Glaser, R.; Regnard, C.; Tulin, A.V. Kinase-mediated changes in nucleosome conformation trigger chromatin decondensation via poly(ADP-ribosyl)ation. Mol. Cell 2014, 53, 831-842. [CrossRef] [PubMed] 
195. Caracciolo, D.; Riillo, C.; Di Martino, M.T.; Tagliaferri, P.; Tassone, P. Alternative Non-Homologous End-Joining: Error-Prone DNA Repair as Cancer's Achilles' Heel. Cancers 2021, 13, 1392. [CrossRef] [PubMed]

196. Wang, X.; Zhao, J. Targeted Cancer Therapy Based on Acetylation and Deacetylation of Key Proteins Involved in Double-Strand Break Repair. Cancer Manag. Res. 2022, 14, 259-271. [CrossRef] [PubMed]

197. Makhov, P.; Uzzo, R.G.; Tulin, A.V.; Kolenko, V.M. Histone-dependent PARP-1 inhibitors: A novel therapeutic modality for the treatment of prostate and renal cancers. Urol. Oncol. 2021, 39, 312-315. [CrossRef]

198. Thomas, C.; Ji, Y.; Lodhi, N.; Kotova, E.; Pinnola, A.D.; Golovine, K.; Makhov, P.; Pechenkina, K.; Kolenko, V.; Tulin, A.V. Non-NAD-Like poly(ADP-Ribose) Polymerase-1 Inhibitors effectively Eliminate Cancer in vivo. EBioMedicine 2016, 13, 90-98. [CrossRef]

199. Karpova, Y.; Guo, D.; Makhov, P.; Haines, A.M.; Markov, D.A.; Kolenko, V.; Tulin, A.V. Poly(ADP)-Ribosylation Inhibition: A Promising Approach for Clear Cell Renal Cell Carcinoma Therapy. Cancers 2021, 13, 4973. [CrossRef]

200. Nieborowska-Skorska, M.; Maifrede, S.; Ye, M.; Toma, M.; Hewlett, E.; Gordon, J.; Le, B.V.; Sliwinski, T.; Zhao, H.; Piwocka, K.; et al. Non-NAD-like PARP1 inhibitor enhanced synthetic lethal effect of NAD-like PARP inhibitors against BRCA1-deficient leukemia. Leuk. Lymphoma. 2019, 60, 1098-1101. [CrossRef]

201. Vidal, E.; Sayols, S.; Moran, S.; Guillaumet-Adkins, A.; Schroeder, M.P.; Royo, R.; Orozco, M.; Gut, M.; Gut, I.; Lopez-Bigas, N.; et al. A DNA methylation map of human cancer at single base-pair resolution. Oncogene 2017, 36, 5648-5657. [CrossRef]

202. Burton, G.W.; Foster, D.O.; Perly, B.; Slater, T.F.; Smith, I.C.; Ingold, K.U. Biological antioxidants. Philos. Trans. R. Soc. B. Biol. Sci. 1985, 311, 565-578. [CrossRef]

203. Chiappa, M.; Guffanti, F.; Bertoni, F.; Colombo, I.; Damia, G. Overcoming PARPi resistance: Preclinical and clinical evidence in ovarian cancer. Drug Resist. Updat. 2021, 55, 100744. [CrossRef] [PubMed]

204. Hobbs, E.A.; Litton, J.K.; Yap, T.A. Development of the PARP inhibitor talazoparib for the treatment of advanced BRCA1 and BRCA2 mutated breast cancer. Expert Opin. Pharmacother. 2021, 22, 1825-1837. [CrossRef]

205. Zhou, P.; Wang, J.; Mishail, D.; Wang, C.Y. Recent advancements in PARP inhibitors-based targeted cancer therapy. Precis. Clin. Med. 2020, 3, 187-201. [CrossRef] [PubMed]

206. Bamezai, S.; Demir, D.; Pulikkottil, A.J.; Ciccarone, F.; Fischbein, E.; Sinha, A.; Borga, C.; Te Kronnie, G.; Meyer, L.H.; Mohr, F.; et al. TET1 promotes growth of T-cell acute lymphoblastic leukemia and can be antagonized via PARP inhibition. Leukemia 2021, 35, 389-403. [CrossRef] [PubMed]

207. Farrar, D.; Rai, S.; Chernukhin, I.; Jagodic, M.; Ito, Y.; Yammine, S.; Ohlsson, R.; Murrell, A.; Klenova, E. Mutational analysis of the poly(ADP-ribosyl)ation sites of the transcription factor CTCF provides an insight into the mechanism of its regulation by poly(ADP-ribosyl)ation. Mol. Cell Biol. 2010, 30, 1199-1216. [CrossRef]

208. Yu, W.; Ginjala, V.; Pant, V.; Chernukhin, I.; Whitehead, J.; Docquier, F.; Farrar, D.; Tavoosidana, G.; Mukhopadhyay, R.; Kanduri, C.; et al. Poly(ADP-ribosyl)ation regulates CTCF-dependent chromatin insulation. Nat. Genet. 2004, 36, 1105-1110. [CrossRef]

209. Zardo, G.; Caiafa, P. The unmethylated state of CpG islands in mouse fibroblasts depends on the poly(ADP-ribosyl)ation process. J. Biol. Chem. 1998, 273, 16517-16520. [CrossRef]

210. de Capoa, A.; Febbo, F.R.; Giovannelli, F.; Niveleau, A.; Zardo, G.; Marenzi, S.; Caiafa, P. Reduced levels of poly(ADP-ribosyl)ation result in chromatin compaction and hypermethylation as shown by cell-by-cell computer-assisted quantitative analysis. FASEB $J$. 1999, 13, 89-93. [CrossRef]

211. Camps, M.; Eichman, B.F. Unraveling a connection between DNA demethylation repair and cancer. Mol. Cell 2011, 44, 343-344. [CrossRef]

212. Christmann, M.; Kaina, B. Epigenetic regulation of DNA repair genes and implications for tumor therapy. Mutat. Res. Rev. Mutat. Res. 2019, 780, 15-28. [CrossRef]

213. Srivastava, R.; Mishra, N.; Singh, U.M.; Srivastava, R. Genotoxicity: Mechanisms and its impact on human diseases. Octa J. Biosci. 2016, 4, 67-70.

214. Scardocci, A.; Guidi, F.; D’Alo, F.; Gumiero, D.; Fabiani, E.; Diruscio, A.; Martini, M.; Larocca, L.M.; Zollino, M.; Hohaus, S.; et al. Reduced BRCA1 expression due to promoter hypermethylation in therapy-related acute myeloid leukaemia. Br. J. Cancer 2006, 95, 1108-1113. [CrossRef] [PubMed]

215. Muvarak, N.E.; Chowdhury, K.; Xia, L.; Robert, C.; Choi, E.Y.; Cai, Y.; Bellani, M.; Zou, Y.; Singh, Z.N.; Duong, V.H.; et al. Enhancing the Cytotoxic Effects of PARP Inhibitors with DNA Demethylating Agents-A Potential Therapy for Cancer. Cancer Cell 2016, 30, 637-650. [CrossRef] [PubMed]

216. Kontandreopoulou, C.N.; Diamantopoulos, P.T.; Tiblalexi, D.; Giannakopoulou, N.; Viniou, N.A. PARP1 as a therapeutic target in acute myeloid leukemia and myelodysplastic syndrome. Blood Adv. 2021, 5, 4794-4805. [CrossRef] [PubMed]

217. Baer, M.R.; Kogan, A.A.; Bentzen, S.M.; Mi, T.; Lapidus, R.G.; Duong, V.H.; Emadi, A.; Niyongere, S.; O'Connell, C.L.; Youngblood, B.A.; et al. Phase I clinical trial of DNA methyltransferase inhibitor decitabine and PARP inhibitor talazoparib combination therapy in relapsed/refractory acute myeloid leukemia. Clin. Cancer Res. 2022. [CrossRef]

218. Li, X.; Li, C.; Jin, J.; Wang, J.; Huang, J.; Ma, Z.; Huang, X.; He, X.; Zhou, Y.; Xu, Y.; et al. High PARP-1 expression predicts poor survival in acute myeloid leukemia and PARP-1 inhibitor and SAHA-bendamustine hybrid inhibitor combination treatment synergistically enhances anti-tumor effects. EBioMedicine 2018, 38, 47-56. [CrossRef]

219. Iacobucci, I.; Qu, C.; Varotto, E.; Janke, L.J.; Yang, X.; Seth, A.; Shelat, A.; Friske, J.D.; Fukano, R.; Yu, J.; et al. Modeling and targeting of erythroleukemia by hematopoietic genome editing. Blood 2021, 137, 1628-1640. [CrossRef] 
220. Barber, L.J.; Sandhu, S.; Chen, L.; Campbell, J.; Kozarewa, I.; Fenwick, K.; Assiotis, I.; Rodrigues, D.N.; Reis Filho, J.S.; Moreno, V.; et al. Secondary mutations in BRCA2 associated with clinical resistance to a PARP inhibitor. J. Pathol. 2013, 229, 422-429. [CrossRef]

221. Kondrashova, O.; Nguyen, M.; Shield-Artin, K.; Tinker, A.V.; Teng, N.N.H.; Harrell, M.I.; Kuiper, M.J.; Ho, G.Y.; Barker, H.; Jasin, M.; et al. Secondary Somatic Mutations Restoring RAD51C and RAD51D Associated with Acquired Resistance to the PARP Inhibitor Rucaparib in High-Grade Ovarian Carcinoma. Cancer Discov. 2017, 7, 984-998. [CrossRef]

222. Lord, C.J.; Ashworth, A. Mechanisms of resistance to therapies targeting BRCA-mutant cancers. Nat. Med. 2013, 19, 1381-1388. [CrossRef]

223. Pulliam, N.; Fang, F.; Ozes, A.R.; Tang, J.; Adewuyi, A.; Keer, H.; Lyons, J.; Baylin, S.B.; Matei, D.; Nakshatri, H.; et al. An Effective Epigenetic-PARP Inhibitor Combination Therapy for Breast and Ovarian Cancers Independent of BRCA Mutations. Clin. Cancer Res. 2018, 24, 3163-3175. [CrossRef] [PubMed]

224. Feng, Y.; Li, X.; Cassady, K.; Zou, Z.; Zhang, X. TET2 Function in Hematopoietic Malignancies, Immune Regulation, and DNA Repair. Front. Oncol 2019, 9, 210. [CrossRef] [PubMed]

225. Chattopadhyaya, S.; Ghosal, S. DNA methylation: A saga of genome maintenance in hematological perspective. Hum. Cell 2022, 35, 448-461. [CrossRef] [PubMed]

226. Ma, C.; Seong, H.; Liu, Y.; Yu, X.; Xu, S.; Li, Y. Ten-eleven translocation proteins (TETs): Tumor suppressors or tumor enhancers? Front. Biosci. Landmark Ed. 2021, 26, 895-915. [CrossRef]

227. Harrision, D.; Gravells, P.; Thompson, R.; Bryant, H.E. Poly(ADP-Ribose) Glycohydrolase (PARG) vs. Poly(ADP-Ribose) Polymerase (PARP)-Function in Genome Maintenance and Relevance of Inhibitors for Anti-cancer Therapy. Front. Mol. Biosci. 2020, 7, 191. [CrossRef]

228. Slade, D. PARP and PARG inhibitors in cancer treatment. Genes Dev. 2020, 34, 360-394. [CrossRef]

229. Tanuma, S.I.; Shibui, Y.; Oyama, T.; Uchiumi, F.; Abe, H. Targeting poly(ADP-ribose) glycohydrolase to draw apoptosis codes in cancer. Biochem. Pharm. 2019, 167, 163-172. [CrossRef]

230. Agarwal, N.; Azad, A.; Shore, N.D.; Carles, J.; Fay, A.P.; Dunshee, C.; Karsh, L.I.; Paccagnella, M.L.; Santo, N.D.; Elmeliegy, M.; et al. Talazoparib plus enzalutamide in metastatic castration-resistant prostate cancer: TALAPRO-2 phase III study design. Future Oncol. 2022, 18, 425-436. [CrossRef]

231. Fenton, S.E.; Chalmers, Z.R.; Hussain, M. PARP Inhibition in Advanced Prostate Cancer. Cancer J. 2021, 27, 457-464. [CrossRef]

232. Rao, A.; Moka, N.; Hamstra, D.A.; Ryan, C.J. Co-Inhibition of Androgen Receptor and PARP as a Novel Treatment Paradigm in Prostate Cancer-Where Are We Now? Cancers 2022, 14, 801. [CrossRef]

233. Mandumpala, J.J.; Baby, S.; Tom, A.A.; Godugu, C.; Shankaraiah, N. Role of histone demethylases and histone methyltransferases in triple-negative breast cancer: Epigenetic mnemonics. Life Sci. 2022, 292, 120321. [CrossRef] [PubMed]

234. Good, C.R.; Panjarian, S.; Kelly, A.D.; Madzo, J.; Patel, B.; Jelinek, J.; Issa, J.J. TET1-Mediated Hypomethylation Activates Oncogenic Signaling in Triple-Negative Breast Cancer. Cancer Res. 2018, 78, 4126-4137. [CrossRef] [PubMed]

235. Ossovskaya, V.; Koo, I.C.; Kaldjian, E.P.; Alvares, C.; Sherman, B.M. Upregulation of Poly (ADP-Ribose) Polymerase-1 (PARP1) in Triple-Negative Breast Cancer and Other Primary Human Tumor Types. Genes Cancer 2010, 1, 812-821. [CrossRef]

236. Sultan, M.; Schulz, M.H.; Richard, H.; Magen, A.; Klingenhoff, A.; Scherf, M.; Seifert, M.; Borodina, T.; Soldatov, A.; Parkhomchuk, D.; et al. A global view of gene activity and alternative splicing by deep sequencing of the human transcriptome. Science 2008, 321, 956-960. [CrossRef] [PubMed]

237. Wang, Z.Q.; Auer, B.; Stingl, L.; Berghammer, H.; Haidacher, D.; Schweiger, M.; Wagner, E.F. Mice lacking ADPRT and poly(ADPribosyl)ation develop normally but are susceptible to skin disease. Genes Dev. 1995, 9, 509-520. [CrossRef] [PubMed]

238. Ménissier de Murcia, J.; Ricoul, M.; Tartier, L.; Niedergang, C.; Huber, A.; Dantzer, F.; Schreiber, V.; Amé, J.C.; Dierich, A.; LeMeur, M.; et al. Functional interaction between PARP-1 and PARP-2 in chromosome stability and embryonic development in mouse. EMBO J. 2003, 22, 2255-2263. [CrossRef] [PubMed]

239. D'Amours, D.; Desnoyers, S.; D'Silva, I.; Poirier, G.G. Poly(ADP-ribosyl)ation reactions in the regulation of nuclear functions. Biochem. J. 1999, 342, 249-268. [CrossRef]

240. Csizmar, C.M.; Saliba, A.N.; Swisher, E.M.; Kaufmann, S.H. PARP Inhibitors and Myeloid Neoplasms: A Double-Edged Sword Cancers 2021, 13, 6385. [CrossRef]

241. Faraoni, I.; Giansanti, M.; Voso, M.T.; Lo-Coco, F.; Graziani, G. Targeting ADP-ribosylation by PARP inhibitors in acute myeloid leukaemia and related disorders. Biochem. Pharm. 2019, 167, 133-148. [CrossRef]

242. Padella, A.; Ghelli Luserna Di Rorà, A.; Marconi, G.; Ghetti, M.; Martinelli, G.; Simonetti, G. Targeting PARP proteins in acute leukemia: DNA damage response inhibition and therapeutic strategies. J. Hematol. Oncol. 2022, 15, 10. [CrossRef]

243. Park, S.; Kim, Y.J.; Huh, H.J.; Chung, H.S.; Lee, M.; Park, Y.M.; Mun, Y.C.; Seong, C.M.; Huh, J. Comprehensive DNA repair gene expression analysis and its prognostic significance in acute myeloid leukemia. Hematology 2021, 26, 904-913. [CrossRef] [PubMed]

244. Collet, L.; Péron, J.; Penault-Llorca, F.; Pujol, P.; Lopez, J.; Freyer, G.; You, B. PARP Inhibitors: A Major Therapeutic Option in Endocrine-Receptor Positive Breast Cancers. Cancers 2022, 14, 599. [CrossRef] [PubMed]

245. Mekhaeil, M.; Dev, K.K.; Conroy, M.J. Existing Evidence for the Repurposing of PARP-1 Inhibitors in Rare Demyelinating Diseases. Cancers 2022, 14, 687. [CrossRef] [PubMed]

246. Yu, J.; Peng, Y.; Wu, L.C.; Xie, Z.; Deng, Y.; Hughes, T.; He, S.; Mo, X.; Chiu, M.; Wang, Q.E.; et al. Curcumin down-regulates DNA methyltransferase 1 and plays an anti-leukemic role in acute myeloid leukemia. PLoS ONE 2013, 8, e55934. [CrossRef] [PubMed]

247. Li, Y.; Meeran, S.M.; Patel, S.N.; Chen, H.; Hardy, T.M.; Tollefsbol, T.O. Epigenetic reactivation of estrogen receptor- $\alpha$ (ER $\alpha$ ) by genistein enhances hormonal therapy sensitivity in ER $\alpha$-negative breast cancer. Mol. Cancer 2013, 12, 9. [CrossRef] 
248. Wang, N.; Wang, Z.; Wang, Y.; Xie, X.; Shen, J.; Peng, C.; You, J.; Peng, F.; Tang, H.; Guan, X.; et al. Dietary compound isoliquiritigenin prevents mammary carcinogenesis by inhibiting breast cancer stem cells through WIF1 demethylation. Oncotarget 2015, 6, 9854-9876. [CrossRef]

249. Qin, W.; Zhang, K.; Clarke, K.; Weiland, T.; Sauter, E.R. Methylation and miRNA effects of resveratrol on mammary tumors vs. normal tissue. Nutr. Cancer 2014, 66, 270-277. [CrossRef]

250. Kanai, Y.; Ushijima, S.; Nakanishi, Y.; Sakamoto, M.; Hirohashi, S. Mutation of the DNA methyltransferase (DNMT) 1 gene in human colorectal cancers. Cancer Lett. 2003, 192, 75-82. [CrossRef]

251. Kanai, Y.; Ushijima, S.; Kondo, Y.; Nakanishi, Y.; Hirohashi, S. DNA methyltransferase expression and DNA methylation of CPG islands and peri-centromeric satellite regions in human colorectal and stomach cancers. Int. J. Cancer 2001, 91, 205-212. [CrossRef]

252. Etoh, T.; Kanai, Y.; Ushijima, S.; Nakagawa, T.; Nakanishi, Y.; Sasako, M.; Kitano, S.; Hirohashi, S. Increased DNA methyltransferase 1 (DNMT1) protein expression correlates significantly with poorer tumor differentiation and frequent DNA hypermethylation of multiple CpG islands in gastric cancers. Am. J. Pathol. 2004, 164, 689-699. [CrossRef]

253. Lin, R.-K.; Wu, C.-Y.; Chang, J.-W.; Juan, L.-J.; Hsu, H.-S.; Chen, C.-Y.; Lu, Y.-Y.; Tang, Y.-A.; Yang, Y.-C.; Yang, P.-C. Dysregulation of p53/Sp1 control leads to DNA methyltransferase-1 overexpression in lung cancer. Cancer Res. 2010, 70, 5807-5817. [CrossRef] [PubMed]

254. Chen, Y.; Tang, Q.; Xiao, Q.; Yang, L.; Hann, S.S. Targeting EP4 downstream c-Jun through ERK1/2-mediated reduction of DNMT1 reveals novel mechanism of solamargine-inhibited growth of lung cancer cells. J. Cell Mol. Med. 2017, 21, 222-233. [CrossRef] [PubMed]

255. Huang, L.; Hu, B.; Ni, J.; Wu, J.; Jiang, W.; Chen, C.; Yang, L.; Zeng, Y.; Wan, R.; Hu, G.; et al. Transcriptional repression of SOCS3 mediated by IL-6/STAT3 signaling via DNMT1 promotes pancreatic cancer growth and metastasis. J. Exp. Clin. Cancer Res. 2016, 35, 27. [CrossRef] [PubMed]

256. Ma, H.S.; Wang, E.L.; Xu, W.F.; Yamada, S.; Yoshimoto, K.; Qian, Z.R.; Shi, L.; Liu, L.L.; Li, X.H. Overexpression of DNA (Cytosine5)-Methyltransferase 1 (DNMT1) And DNA (Cytosine-5)-Methyltransferase 3A (DNMT3A) Is Associated with Aggressive Behavior and Hypermethylation of Tumor Suppressor Genes in Human Pituitary Adenomas. Med. Sci. Monit. 2018, 24, 4841-4850. [CrossRef]

257. Zhang, Y.; Sun, B.; Huang, Z.; Zhao, D.-W.; Zeng, Q. Shikonin inhibites migration and invasion of thyroid cancer cells by downregulating DNMT1. Med. Sci. Monit. 2018, 24, 661. [CrossRef]

258. Yan, X.-J.; Xu, J.; Gu, Z.-H.; Pan, C.-M.; Lu, G.; Shen, Y.; Shi, J.-Y.; Zhu, Y.-M.; Tang, L.; Zhang, X.-W. Exome sequencing identifies somatic mutations of DNA methyltransferase gene DNMT3A in acute monocytic leukemia. Nat. Genet. 2011, 43, 309-315. [CrossRef]

259. Zhou, L.; Fu, L.; Lv, N.; Liu, J.; Li, Y.; Chen, X.; Xu, Q.; Chen, G.; Pang, B.; Wang, L. Methylation-associated silencing of BASP1 contributes to leukemogenesis in $\mathrm{t}(8 ; 21)$ acute myeloid leukemia. Exp. Mol. Med. 2018, 50, 1-8.

260. Leonard, S.; Pereira, M.; Fox, R.; Gordon, N.; Yap, J.; Kehoe, S.; Luesley, D.; Woodman, C.; Ganesan, R. Over-expression of DNMT3A predicts the risk of recurrent vulvar squamous cell carcinomas. Gynecol. Oncol. 2016, 143, 414-420. [CrossRef]

261. Qiu, W.; Lin, J.; Zhu, Y.; Zhang, J.; Zeng, L.; Su, M.; Tian, Y. Kaempferol modulates DNA methylation and downregulates DNMT3B in bladder cancer. Cell. Physiol. Biochem. 2017, 41, 1325-1335. [CrossRef]

262. Roll, J.D.; Rivenbark, A.G.; Jones, W.D.; Coleman, W.B. DNMT3b overexpression contributes to a hypermethylator phenotype in human breast cancer cell lines. Mol. Cancer 2008, 7, 15. [CrossRef]

263. Lai, S.-C.; Su, Y.-T.; Chi, C.-C.; Kuo, Y.-C.; Lee, K.-F.; Wu, Y.-C.; Lan, P.-C.; Yang, M.-H.; Chang, T.-S.; Huang, Y.-H. DNMT3b/OCT4 expression confers sorafenib resistance and poor prognosis of hepatocellular carcinoma through IL-6/STAT3 regulation. J. Exp. Clin. Cancer Res. 2019, 38, 474. [CrossRef] [PubMed]

264. Kuck, D.; Caulfield, T.; Lyko, F.; Medina-Franco, J.L. Nanaomycin A selectively inhibits DNMT3B and reactivates silenced tumor suppressor genes in human cancer cells. Mol. Cancer Ther. 2010, 9, 3015-3023. [CrossRef] [PubMed]

265. Zhao, L.; Shou, H.; Chen, L.; Gao, W.; Fang, C.; Zhang, P. Effects of ginsenoside Rg3 on epigenetic modification in ovarian cancer cells. Oncol. Rep. 2019, 41, 3209-3218. [CrossRef] [PubMed]

266. Dolnik, A.; Engelmann, J.C.; Scharfenberger-Schmeer, M.; Mauch, J.; Kelkenberg-Schade, S.; Haldemann, B.; Fries, T.; Kronke, J.; Kuhn, M.W.; Paschka, P.; et al. Commonly altered genomic regions in acute myeloid leukemia are enriched for somatic mutations involved in chromatin remodeling and splicing. Blood 2012, 120, e83-e92. [CrossRef] [PubMed]

267. Gui, Y.; Guo, G.; Huang, Y.; Hu, X.; Tang, A.; Gao, S.; Wu, R.; Chen, C.; Li, X.; Zhou, L.; et al. Frequent mutations of chromatin remodeling genes in transitional cell carcinoma of the bladder. Nat. Genet. 2011, 43, 875-878. [CrossRef]

268. Quesada, V.; Conde, L.; Villamor, N.; Ordonez, G.R.; Jares, P.; Bassaganyas, L.; Ramsay, A.J.; Bea, S.; Pinyol, M.; Martinez-Trillos, A.; et al Exome sequencing identifies recurrent mutations of the splicing factor SF3B1 gene in chronic lymphocytic leukemia. Nat. Genet. 2011, 44, 47-52. [CrossRef]

269. Cancer Genome Atlas Network. Comprehensive molecular characterization of human colon and rectal cancer. Nature 2012, 487, 330-337. [CrossRef]

270. Seshagiri, S.; Stawiski, E.W.; Durinck, S.; Modrusan, Z.; Storm, E.E.; Conboy, C.B.; Chaudhuri, S.; Guan, Y.; Janakiraman, V.; Jaiswal, B.S.; et al. Recurrent R-spondin fusions in colon cancer. Nature 2012, 488, 660-664. [CrossRef]

271. Scourzic, L.; Mouly, E.; Bernard, O.A. TET proteins and the control of cytosine demethylation in cancer. Genome Med. 2015, 7, 9. [CrossRef] 
272. Kan, Z.; Jaiswal, B.S.; Stinson, J.; Janakiraman, V.; Bhatt, D.; Stern, H.M.; Yue, P.; Haverty, P.M.; Bourgon, R.; Zheng, J.; et al. Diverse somatic mutation patterns and pathway alterations in human cancers. Nature 2010, 466, 869-873. [CrossRef]

273. Imielinski, M.; Berger, A.H.; Hammerman, P.S.; Hernandez, B.; Pugh, T.J.; Hodis, E.; Cho, J.; Suh, J.; Capelletti, M.; Sivachenko, A.; et al. Mapping the hallmarks of lung adenocarcinoma with massively parallel sequencing. Cell 2012, 150, 1107-1120. [CrossRef] [PubMed]

274. Seo, J.S.; Ju, Y.S.; Lee, W.C.; Shin, J.Y.; Lee, J.K.; Bleazard, T.; Lee, J.; Jung, Y.J.; Kim, J.O.; Shin, J.Y.; et al. The transcriptional landscape and mutational profile of lung adenocarcinoma. Genome Res. 2012, 22, 2109-2119. [CrossRef] [PubMed] 